Article

\title{
Gene Expression, Bacteria Viability and Survivability Following Spray Drying of Mycobacterium smegmatis
}

\author{
Elizabeth Hunter Lauten ${ }^{1}$, Brian L. Pulliam ${ }^{1, *}$, Jessica DeRousse ${ }^{1}$, Deen Bhatta ${ }^{1}$ and \\ David A. Edwards ${ }^{2,3, *}$
}

1 Harvard School of Engineering and Applied Sciences, 58 Oxford Street, ESL 406, Cambridge, MA 02138, USA; E-Mails: lauteneh@seas.harvard.edu (E.H.L.); jderouss@seas.harvard.edu (J.D.); dbhatta@seas.harvard.edu (D.B.)

2 Harvard School of Engineering and Applied Sciences, 29 Oxford Street, 322 Pierce Hall, Cambridge, MA 02138, USA

3 Wyss Institute of Biologically Inspired Engineering, Harvard University HIM, 10th Floor,4 Blackfan Circle, Boston, MA 02115, USA

* Authors to whom correspondence should be addressed; E-Mail: dedwards@seas.harvard.edu (D.A.E.); bpulliam@medicineinneed.org (B.L.P.); Tel.: +1-617-495-1328; Fax: +1-617-495-9837.

Received: 13 January 2010; in revised form: 23 March 2010 / Accepted: 8 April 2010 /

Published: 13 April 2010

\begin{abstract}
We find that Mycobacterium smegmatis survives spray drying and retains cell viability in accelerated temperature stress $\left(40{ }^{\circ} \mathrm{C}\right)$ conditions with a success rate that increases with increasing thermal, osmotic, and nutrient-restriction stresses applied to the mycobacterium prior to spray drying. $M$. smegmatis that are spray dried during log growth phase, where they suffer little or no nutrient-reduction stress, survive for less than 7 days in the dry powder state at accelerated temperature stress conditions, whereas M. smegmatis that are spray dried during stationary phase, where cells do suffer nutrient reduction, survive for up to 14 days. M. smegmatis that are spray dried from stationary phase, subjected to accelerated temperature stress conditions, regrown to stationary phase, spray dried again, and resubmitted to this same process four consecutive times, display, on the fourth spray drying iteration, an approximate ten-fold increase in stability during accelerated temperature stress testing, surviving up to 105 days. Microarray tests revealed significant differences in genetic expression of $M$. smegmatis between log phase and stationary phase conditions, between naïve (non spray-dried) and multiply cycled dried $M$. smegmatis (in log and stationary phase), and between M. smegmatis in the dry powder
\end{abstract}


state following a single spray drying operation and after four consecutive spray drying operations. These differences, and other phenotypical differences, point to the carotenoid biosynthetic pathway as a probable pathway contributing to bacteria survival in the spraydried state and suggests strategies for spray drying that may lead to significantly greater room-temperature stability of mycobacteria, including mycobacterium bovis bacille Calmette-Guerin (BCG), the current TB vaccine.

Keywords: mycobacterium; gene expression; thermostability

\section{Introduction}

Tuberculosis kills more than three million people annually and is ranked among the top ten causes of global mortality and morbidity [1]. The current Mycobacterium bovis bacille Calmette-Guerin (BCG) TB vaccine, which is given intradermally to 100 million infants annually, is formulated as a dry powder via freeze drying (lyophilization) [2,3]. This process typically results in a live attenuated vaccine with $10-30 \%$ viability relative to the pre-dried formulation [4]. When kept at refrigerated conditions the commercial lyophilized BCG loses approximately one log of activity after one year to 18 months on the shelf. This is dramatically reduced when placed at room temperature stability conditions $\left(25^{\circ} \mathrm{C}\right)$ resulting in a month or two of accepted viability [1]. Preserving the viability of BCG in dried powders is thought to be an important factor in the potency of the vaccine [5]. Thermostability is of particular importance due to the rugged conditions typically encountered in the regions of the world affected by infectious disease.

Previous work in our lab has shown that we have been able to improve on the typical viability and stability achieved through lyophilization. This is done by spray drying the bacteria in a dilute osmolyte solution. Increasing the osmolyte concentration in spray dried solution leads to less viability ultimately reflecting stresses that lead to cell death [6].

In general mycobacteria have well known cellular responses to environmental crisis and stresses such as heat shock, cold shock, nutrient limitation, and osmotic and oxidative stresses [7]. During the formulation process mycobacteria are exposed to stresses, which can cause cell damage and death. It is likely that bacteria that can survive the spray drying process more significantly express protective agents that render these bacteria more resistant to osmotic, heat and nutrient limitation stresses. We have therefore hypothesized that by repeatedly exposing bacteria to stresses involved in the processes of spray drying and dry state containment, we might succeed in selecting for bacteria populations with greater biochemical and biophysical ability to survive.

We chose to work with $M$. smegmatis as an illustrative mycobacterium given relative rapid growth and previous experience in spray drying. We spray dry $M$. smegmatis in dilute osmolyte conditions, recover the dry powder and expose the dry powder to $40{ }^{\circ} \mathrm{C}$ conditions sufficiently long enough to eliminate nearly all viable bacteria. We then re-suspend the highly stressed dry powder in culture media and grow the remaining live bacteria to stationary phase. This process was repeated (cycled) several times after which we examined the bacterial RNA through microarrays to quantify differences in gene expression. 
By selecting viable bacteria in harsh stability conditions and identifying protective factors that allow them to survive, we hope to identify mechanisms through which highly robust and thermostable bacteria may be formulated so as to persist in the dry powder state. Ideally these results could then be applied to a broad range of live or attenuated whole-cell vaccines against infectious pathogens including M. tuberculosis.

\section{Results and Discussion}

M. smegmatis cultures were formulated into dry powders and placed in accelerated stability conditions at $40{ }^{\circ} \mathrm{C}$ and the viability was followed over time. The dry powders were prepared from: (1) bacteria growing in optimal exponential growth phase conditions (2) bacteria that had entered stationary phase and (3) bacteria that were exposed to repeated spray drying and post-drying exposure to $40{ }^{\circ} \mathrm{C}$ conditions - for four cycles of spray drying.

\subsection{Viability}

As illustrated in Figure 1, bacteria dried after growing in log phase conditions exhibit the least resistance to the accelerated stability conditions, resulting in complete loss of viability within 7 days $(n=3)$. When the bacteria are grown to stationary phase for 24 hours, and then spray dried, they are able to survive longer in the desiccated state at accelerated stability conditions, with no detectable colonies after 14 days $(n=3)$. Viability over time in the desiccated state continued to increase as the formulations were cycled through the drying and heat-exposure process. "Cycling" consisted of repeated application of the following steps: first culturing bacteria to stationary phase, then processing cultures for spray drying (centrifugation and re-suspension in low osmolyte excipient solutions), then spray drying, then collecting and processing the dry powder (vial filling), then incubating the vials at $40{ }^{\circ} \mathrm{C}$ in stability chambers until viable bacteria were mostly eliminated, then culturing surviving bacteria from dry powder to stationary phase. After repeating the cycle four times ("multiply cycled bacteria") the bacteria showed an almost 10 -fold increase in stability with the ability to form colonies until 105 days $(\mathrm{n}=3)$. 
Figure 1. Viability comparison of dry powder $M$. smegmatis spray dried under various conditions. Normalized $\log$ CFU viability of $M$. smegmatis spray dried at log phase growth and stored at $40{ }^{\circ} \mathrm{C}(\bullet)$. Normalized $\log \mathrm{CFU}$ viability of $M$. smegmatis spray dried at stationary phase growth and stored at $40{ }^{\circ} \mathrm{C}(\boldsymbol{\Delta})$. Normalized $\log \mathrm{CFU}$ viability of multiply cycled $M$. smegmatis stored at $40{ }^{\circ} \mathrm{C}(\diamond)$. Error bars represent maximum and minimum $\mathrm{CFU}$ at each time point across $n$. For cycled bacteria $n=3$ was performed on the final (fourth) cycle.

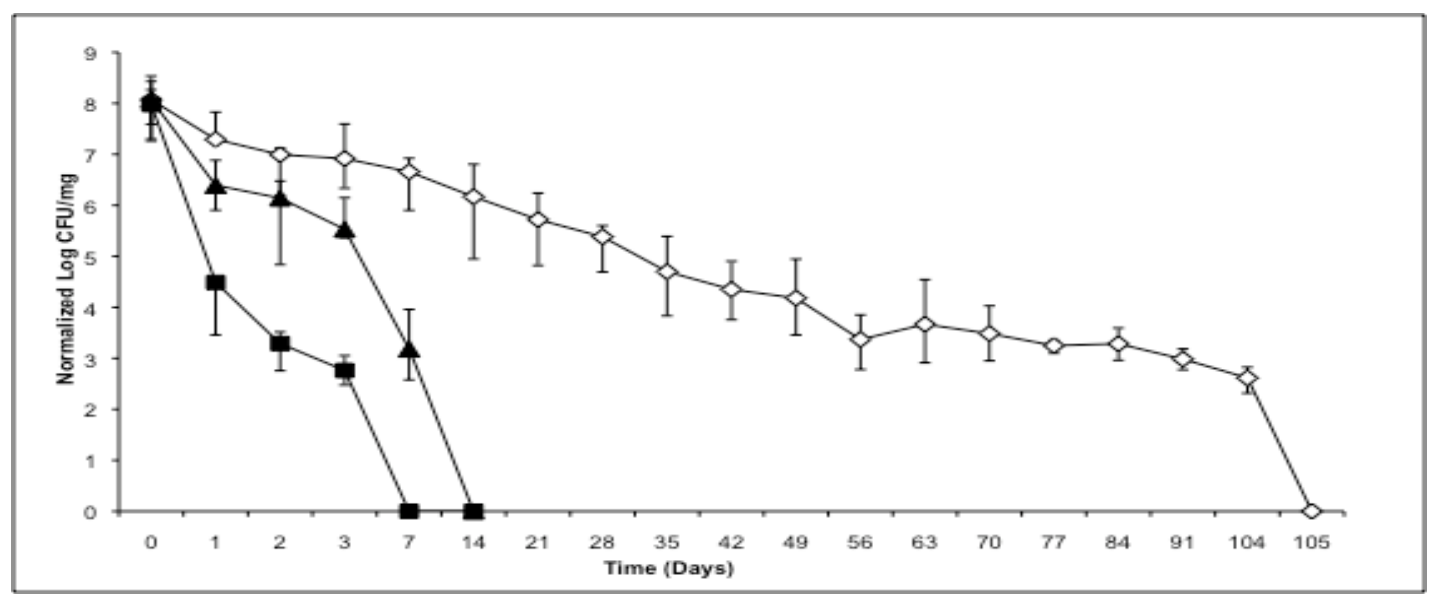

\subsection{Phenotype}

The increased viability over time of multiply cycled bacteria was accompanied by some minor changes in growth rate and overall gross morphology differences between the colony forming units. In $\log$ growth phases, the wild type non-spray dried bacteria exhibited a doubling time of $2.4 \pm 0.3$ hours $(\mathrm{n}=3)$, whereas multiply cycled bacteria doubled approximately every $3.1 \pm 0.1$ hours $(\mathrm{n}=3)$ (Figure 2). Surface topology was identical between colonies with both the non-previously spray dried bacteria and the multiply cycled bacteria exhibiting rough morphology. Strikingly, the color of the multiply cycled bacteria colonies differed from the non-spray dried bacteria. Approximately $30 \pm 5 \%$ of the colonies on multiply cycled plates were orange pigmented upon removal from the plate incubator whereas only $5 \pm 3 \%$ of the wild type non-spray dried plates were orange colored upon removal. This pigmented phenotype began to emerge after the second spray drying cycle and became dominant by the fourth cycle. The proportion of multiply cycled colonies exhibiting pigmentation, as well as the intensity of the pigmentation, increased when plates were left on the bench-top and exposed to light and air. The percentage of heavily pigmented colonies grew to greater than $90 \% \pm 5 \%$ after 1 day exposure to light and air (Figure 3). 
Figure 2. Optical density growth curves over time of non-spray dried M. smegmatis $(\bullet)$ and multiply cycled $M$. smegmatis $(\bullet)$.

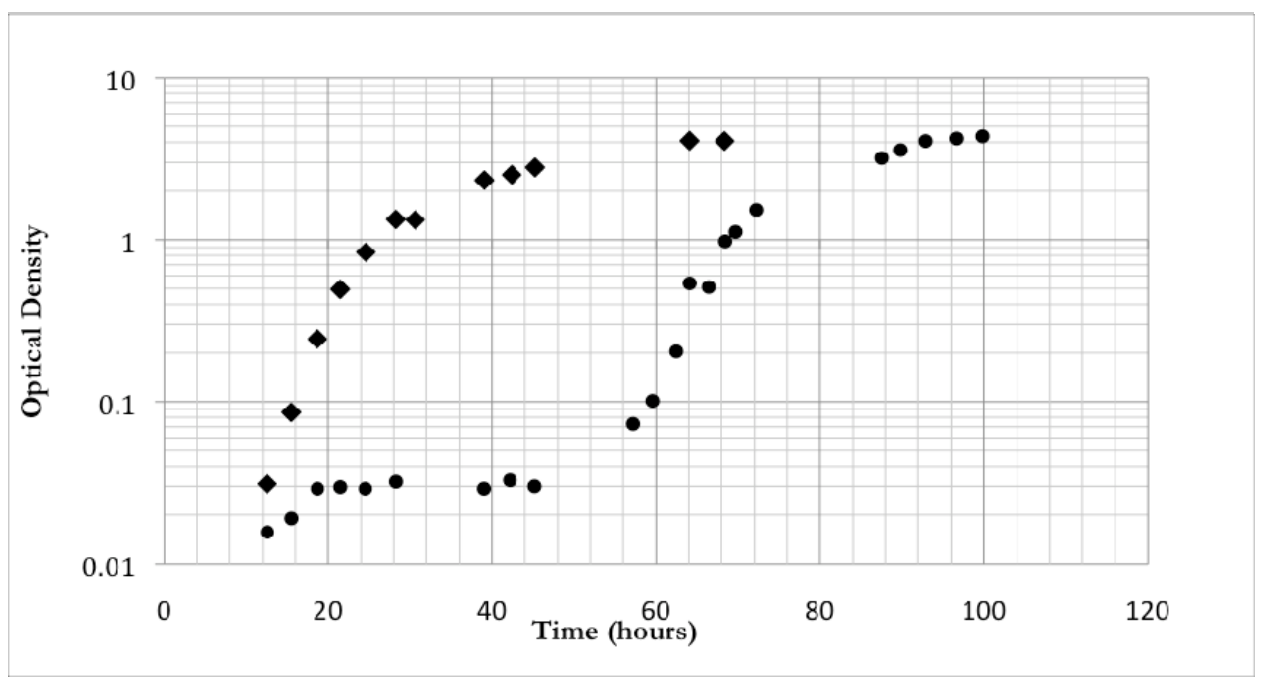

Figure 3. M. smegmatis colony forming units of (a) wild-type non-spray dried bacteria and (b) multiply-cycled bacteria after 1 day exposure to light and air. Bacteria are not exposed to light during incubation. The orange phenotype will emerge in the wild-type strain after exposure to air and light at low frequency. Multiply-cycled bacteria emerge from the incubator with the orange phenotype which becomes more intense upon exposure to light and air.

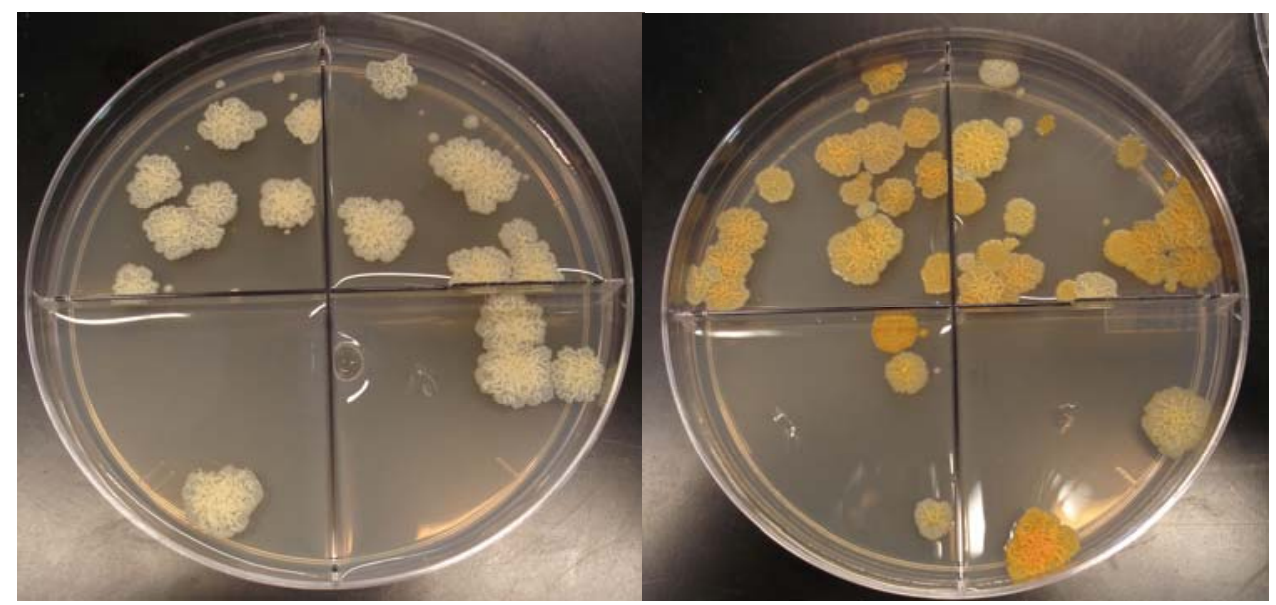

\subsection{Gene Expression}

We performed two sets of gene expression experiments to uncover factors important for sustained viability in the dry powder formulation process. In the first experiment we examined gene expression in log phase and stationary phase cultures of bacteria, neither of which had been previously exposed to spray drying. In our second set of experiments we compared gene expression in non-previously spray dried bacteria to that in multiply spray dried bacteria. In this case we made head-to-head comparisons in log phase, stationary phase, and dry powders that had 24 hour exposure to accelerated stress conditions. 


\subsubsection{Log versus Stationary Comparison in Non-Spray Dried Cultures}

We extracted RNA from log phase (O.D. $=1.0)$ and stationary phase (O.D. $>3.0$ ) bacteria and performed four microarrays - two biological replicates each with a dye swap to minimize dye specific bias. As expected, significant differential gene expression was observed. Out of approximately 7000 genes on the microarray, about 2500 were differentially expressed at a p-value $<0.05$ level of significance. Out of these 2500 genes, approximately 1400 were differentially expressed with a pvalue $<0.01$. The $\log 2$ median average intensity of the $M$. smegmatis spots was 9.8 whereas the median average intensity for the A. thaliana control spots was 7.2. This indicated that signal was, on average, 5-fold greater than non-specific cross-hybridization noise.

Genes up-regulated in log phase over stationary phase included a nearly complete complement of ribosomal proteins (Appendix Table 1) as well genes that are important for growth including electron transport (e.g. ATP synthase components), energy metabolism (e.g. TCA cycle enzymes), and cell maintenance needs (e.g. lipid metabolism and protein folding) (Appendix Table 2). Genes upregulated in stationary phase over log phase included those typically associated with states of stress including catalases, nitrite reductases, alternative sigma factors, and various amino acid permeases and transporters (Appendix Table 3). Two clusters related to the expression and assembly of [NiFe] hydrogenase were up-regulated along with other stress related genes included UsfY (MSMEG_1769 and MSMEG_1791), the starvation-induced DNA protecting protein (MSMEG_6467), the sporulation factor WhiB (MSMEG_1597 and MSMEG_1953), and L-lysine-epsilon aminotransferase (MSMEG_1764).

Since differential regulation of gene expression is mainly controlled by the presence of primary and alternative sigma factors we expected to see significant up-regulation of MysA (primary housekeeping factor) in $\log$ phase and sigB and sigF in stationary phase (stress related factors) [8]. While we found that these were three of the six most highly expressed transcripts, as measured by average intensity across all channels, there was little evidence of differential expression (Appendix Table 4). Instead we found that two sigma factors related to the sigma-54 factor (nitrogen limitation and alternative carbon utilization [9]) and two sigD factors (alternative stress [10]) were most differentially expressed with respect to stationary phase as well as a large $(100 \mathrm{kD})$, uncharacterized sigma factor expressed with respect to $\log$ phase.

\subsubsection{Non-Previously Spray Dried versus Cycled}

In our second set of experiments, we performed microarray analysis that compared gene expression in bacteria that had never been spray dried to that in bacteria that had been subjected to multiple spray drying cycles. We compared the differently processed bacteria by performing four microarrays in $\log$ phase (two biological replicates each with a dye swap), three microarrays in stationary phase (two biological replicates with a single swap), and two microarrays in dry powder form (single biological sample with a dye swap). In the log phase comparison, 79 genes were differentially expressed with a p-value $<0.05$ of which 36 were differentially expressed at a p-value $<0.01$ level of significance. All but two of these genes, acyl-CoA dehrydrogenase (MSMEG_1821) and malonyl CoA-acyl carrier protein transacylase (MSMEG_4325), were upregulated in the multiply cycled bacteria. 
In the stationary phase comparison there were no genes differentially expressed at p-value $<0.05$ level of significance. However, using the log odds scores calculated by the Limma statistical package we found that there were ten genes that had $50 \%$ or greater probability of differential expression (three up-regulated in non-cycled bacteria and seven up-regulated in multiply cycled bacteria - see Appendix Table 6). In addition, there was a significant number that had some ( $>10 \%)$ probability of differential expression. In the dry powder comparison there was a much higher level of differential expression. Approximately 1200 genes were differentially expressed with p-value $<0.05$, however, of these only 140 had a p-value $<0.01$ and the number of genes that had a $50 \%$ or greater chance of being differentially expressed was only 291 . The median average intensity for the M. smegmatis spots in this comparison was 8.3 , approximately 2 -fold below the medians for both the log phase (9.1) and the stationary phase (9.5) comparisons indicating a lower level of signal.

\subsubsection{Log Phase Comparison}

Results for the log phase differential expression data are given in Appendix Table 5. The differentially expressed genes are dominated by a large gene cluster $(22 \%$ of the statistically significant genes) that runs from MSMEG_1766 to MSMEG_1802. Two copies of the UsfY gene product (MSMEG_1769; MSMEG_1777) in the cluster are differentially expressed whereas a third copy of UsfY in the cluster (MSMEG_1791), the one that is closest upstream to sigF and most highly expressed in stationary phase, is not differentially expressed. A fourth copy of UsfY (MSMEG_4406) elsewhere in the genome is also not expressed. SigF is likely expressed, based on an intensity 1.2 standard deviations above the median average intensity, but not differentially (intensity ratio $=0.1$ ). S-(hydroxymethyl) glutathione dehydrogenase is differentially expressed at two loci (MSMEG_0671; MSMEG_6616). Also differentially expressed were genes involved in the acquisition or production of osmolytes and carotenoid antioxidants (e.g. MSMEG_2926 and MSMEG_3184; MSMEG_2345 and MSMEG_2346), two catalases (MSMEG_6213; MSMEG_6232), and the starvation-induced DNA protecting protein (MSMEG_6467).

\subsubsection{Stationary Phase Comparison}

Stationary phase microarray data did not have any statistically significant differentially expressed genes. However, many transcripts did have positive probability of differential expression (Appendix Table 6) with phytoene synthase (MSMEG_2346) having the highest probability of differential expression (66\%). Other differentially expressed transcripts include phytoene dehydrogenase (MSMEG_2347), which participates in the same biosynthetic pathway as phytoene synthase, a manganese containing catalase (MSMEG_6213), maltooligosyl trehalose synthase (MSMEG_3185), S-(hydroxymethyl) glutathione dehydrogenase (MSMEG_0671), and the MSMEG_1769 locus of UsfY. Genes appearing in the stationary phase comparison but not in the log phase comparison include glycerol kinase (MSMEG_6759), glycerol-3-phosphate dehydrogenase 2 (MSMEG_6761), and AmiB (MSMEG_1679). Notably, these three genes were down-regulated relative to the cycled bacteria. SigB (MSMEG_2752) was up-regulated in this comparison where it was not observed to be differentially expressed in the previous non-previously spray dried log versus stationary phase experiments. 


\subsubsection{Dry Powder Comparison}

The dry powder comparison showed that the non-cycled bacteria increased transcriptional expression of genes associated with growth processes (Appendix Table 7). These transcripts included those for glycolysis (MSMEG_4107), sulfur uptake (MSMEG_5789), fatty acid metabolism (MSMEG_2081; MSMEG_6512), and amino-acid biosynthesis (MSMEG_1843). In addition, there were expressed transcripts related to shut-down or repair including those for amino acid scavenging (MSMEG_5486; MSMEG_6332), oxidative damage (MSMEG_3215), nucleic acid degradation (MSMEG_3902; MSMEG_5226), and the soluble pyridine nucleotide transhydrogenase (MSMEG_2748), which catalyzes the conversion of NADH to NADPH and is important for catabolic processes. Genes expressed at higher levels in cycled bacteria contained a number of genes related to lipid synthesis, a diverse group of transposable elements, the stress related sigD alternative sigma factor (MSMEG_1599), and the error-prone DNA polymerase IV (MSMEG_2748) (Appendix Table 8).

\subsection{Viability Discussion}

The results of this study show that the processing of bacteria into a dry powder state affects overall fitness and ultimately survivability. It is important that fitness, or the ability to respond appropriately to specific stress conditions, not require processing conditions that inhibit the bacteria's ability to flourish in normal growth or other environments. In this light it is important that the bacteria show improved viability over time when grown to stationary phase and exposed multiple times to accelerated stability conditions and the spray drying process. Although the cycled $M$. smegmatis doubles at a slightly slower rate, 3.12 hours vs. 2.36 hours, both times are well within the literature reported values of the bacteria's doubling time under normal growing conditions [11,12]. Furthermore, we found little evidence in the gene expression data to suggest that the observed variability in growth rate was related to transcriptional differences. There was no differential expression observed in genes central to growth or maintenance and limited differential expression overall. However, the genes that were differentially expressed were heavily skewed in number towards the cycled bacteria. The additional expression in cycled bacteria could represent a small increased energy demand in which case the observed slower metabolism might be a genuine consequence of our formulation process.

\subsection{Gene Expression Differences}

Our expression data illustrate that the transition to growth phase from stationary phase is a smooth and highly orchestrated switch in metabolic profile. Stationary phase is a natural response to stressful conditions and bacteria have robust systems in place to counter environmental challenges. In stationary phase of both non-cycled and cycled bacteria we observed increased expression of products that are used to fight stress. These products (Appendix Table 3) included those that combat reactive oxygen species [13], compensate for nitrogen limitation [14], facilitate the utilization of alternative carbon sources [15], and provide for metabolic scavenging [16]. The upregulation of these [NiFe] hydrogenase related genes suggests a response to oxygen limitation ([NiFe] hydrogenases have been shown to be strongly upregulated in hypoxic conditions [17]). Intriguingly, L-lysine-epsilon 
aminotransferase has been shown to be 40-fold up-regulated in models of the persistent/latent infection of M. tuberculosis [18]. It is probable then that the observed increase in dry powder viability of stationary phase cultures over log phase cultures is a consequence of bacteria being better suited to resist harsh conditions.

In a similar vein, our data suggest that in repeatedly stressing bacteria we have enriched the capacities by which bacteria can survive new and specific stress conditions. Interestingly, these capacities seem to be manifested such that the cycled bacteria "anticipate" future stress. For example, the over-production of trehalose biosynthetic enzymes (trehalose is an excellent osmoprotectant), catalases (to neutralize reactive oxygen species), and glutathiones (for alternative carbon utilization and antioxidant activity) occurs in both log and stationary phases of cycled bacteria. Glycerol kinase and glycerol-3-phosphate dehydrogenase 2 are both down-regulated in stationary phase in cycled bacteria. Since both of these enzymes are involved in processing of glycerol, the down-regulation of these two enzymes has the likely effect of increasing intracellular glycerol concentrations. Given that glycerol is another highly effective osmoprotectant (and water substitute), accumulation undoubtedly helps protect against the osmotic forces at work in the drying process and in the dry powder state. Likewise, AmiB, which plays a role in maintenance and disassembly of the extra-cellular polysaccharide capsid, is also down-regulated in stationary phase in cycled bacteria. It may make "survival-sense" for bacteria to reduce degradation of an all important cell barrier if stress is on the horizon. Moreover, a very interesting result was that of the starvation-induced DNA protecting enzyme which is over-produced beginning in log phase growth. This protein is known to exist in two multimeric forms with the extended polymeric form conferring the principle protection of DNA [19]. The transition from the limited multimeric form to the extended polymeric form is temperature dependent, occurring at $40{ }^{\circ} \mathrm{C}$. Since our spray drying was carried out at $+40^{\circ} \mathrm{C}$ and powders subsequently incubated at $40{ }^{\circ} \mathrm{C}$ for extended periods of time, it is possible to speculate that the observed increase in expression is a direct response to our processing conditions. That is, since there is a significant amount of DNA to protect in the event of heat stress, and our processing occurs rapidly, it clearly benefits the organism to accumulate this protein preemptively.

\subsection{Carotenoids}

One striking observation in our study was the marked orange color and continued rapid orange transformation of the cycled bacteria. It was observed however that a fraction of colonies from wild type cultures would also undergo a similar color transformation. It is known that stock cultures of $M$. smegmatis often contain pigmented colonies (as well as other variants) suggesting multiple subpopulations exist or arise naturally in the $\mathrm{mc}^{2} 155$ strain [20]. In our case this phenotype emerged dominantly when large populations were repeatedly spray dried and placed in the stressful environment of a heated dry powder suggesting the orange phenotype may be related to a selective advantage.

Carotenoids are a class of isoprenoid metabolites synthesized de novo in bacteria. The carotenoid pathway ultimately results in pigmented complex polyterpene lipids including-carotene and lycopene whose functions are in part to act as free radical scavengers and protect cells from light induced oxygen species [21]. The carotenoids are also known to be able to contribute to enhancing the strength 
of the cell wall due to their lipophilic nature and intercalation into the cell membrane [22]. The presence of gene products that catalyze the formation of these compounds almost certainly explains the pigmentation appearing in the multiply cycle bacteria including the observed increase in color intensity when exposed to light and dry air on the benchtop. Since carotenoids are robust antioxidants and fortifiers of cellular barriers they would be beneficial for withstanding the shear and osmotic stress in the dry powder formulation procedure. In fact, the buff colored $\mathrm{mc}^{2} 155$ strain of M. smegmatis is known to be less robust relative to the naturally pigmented wild-type strains, having seen ongoing usage as a model organism, in part, for its high transformation efficiency [23,24]. Thus, we feel the putative over-production of these compounds in cycled bacteria would support our hypothesis that prestressed bacteria are more robust.

Analysis of the microarray data showed that the entire carotenoid biosynthetic operon is upregulated in the cycled bacteria in both log and stationary phases (Appendix Table 9). We note that the pathway is not differentially expressed in the dry powder state, however, the high signal intensity over both the cycled and non-cycled samples (all five genes in the operon had expression levels two standard deviations or higher than the median expression level) suggests that it is highly expressed in both cases.

Importantly, previous work conducted in our lab investigated the effects of adding the commercial adjuvants titermax and titermax gold in attempts to increase immunity and antigenicity in spray dried bacteria. It turns out that the major component of the commercial adjuvant formulations are squalene derivatives. These structures have highly similar structure properties with the naturally occurring mycobacteria carotenoids such as zeta-carotene (Figure 4). Remarkably these adjuvant/bacteria formulations also showed a 1-5 log improvement in viability over time in the dried powder state (unpublished data). This suggests that cartenoid and squalene derivatives may play a critical role in increasing viability of organisms in formulation processes and in the dry powder state over time.

Figure 4. Structures of (a) zeta-carotene and (b) squalene.

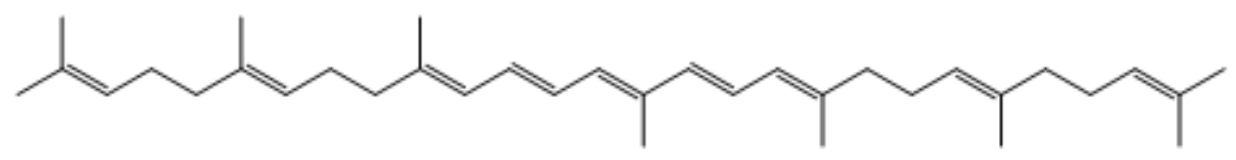

a

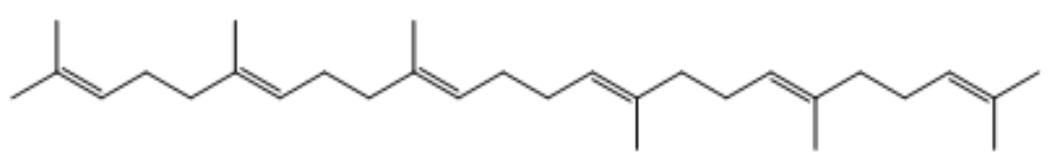

b

\subsection{Stress Response Gene Cluster}

The observation that the gene cluster [MSMEG_1750 to MSMEG_1804] is up-regulated in cycled bacteria is a significant observation. Several genes in this cluster are thought to be related to or regulated by the alternative sigma factors sigF and sigD, including three copies of UsfY (upstream of 
sigma $\underline{\mathrm{F}}$ protein $\underline{\mathrm{Y}}$ ). This cluster of genes is highly similar to a cluster of stress related genes (also containing UsfY) that is implicated in the latency and persistence of M. tuberculosis [25,26].

It has been postulated that UsfY is an anti-anti-sigma factor directed at sigF [25]. Sigma factors act as critical regulators of gene expression in bacteria by recognizing their cognate promoters and controlling the different programs that bacteria employ in response to environmental stimuli. Antisigma factors bind to sigma factors to down-regulating specific transcriptional activity. In turn antianti-sigma factors bind to anti-sigma factors and thus dampen their regulatory activity. Thus, upregulation of UsfY would help explain the increased levels of sigF-dependent transcripts in stressed bacteria.

It has been shown that carotenoid biosythesis genes are regulated by sigF in M. smegmatis [21]. Given the high level of gene expression we observed in the carotenoid biosynthetic pathway, as well as in the cluster of genes related to sigF, we did a simple promoter search in the $M$. smegmatis genome for the sigF consensus promoter sequence -10 (GGGTTT) [26]. The results were striking. A large number of genes that were seen to be either differentially expressed in the cycled bacteria ( $\log$ and/or stationary phase), or highly expressed in the dry powder state, appear to be directly regulated by sigF (Appendix Table 10). In addition, it appears that the MSMEG_1777 locus of UsfY is itself regulated by sigF. Since sigF itself was not seen to be differentially expressed in any of the experiments, including the non-spray dried log versus stationary phase comparison, higher levels of sigF controlled products in the cycled bacteria was puzzling. One possibility is that higher levels of these products could have arisen from increased UsfY expression, at other locus not under control of sigF, combined with basal sigF expression. This, by itself, might account for the observed improvement in viability of cycled bacteria. However, the high expression levels and postulated anti-anti-sigF activity of UsfY, along with the positive regulation by sigF (at least at the MSMEG_1777 locus) may provide for a mechanism by which the cycled bacteria produce larger quantities of important products in a just-intime manner, thus conserving resources while simultaneously being prepared to better survive the dry powder formulation. The mechanism may be that UsfY acts like a positive gain in a control circuit. That is, since UsfY is positively regulated by sigF, higher levels of sigF lead to higher the levels of UsfY, and because of the anti-anti sigma factor activity, higher levels of UsfY lead to higher activity of sigF and consequently higher levels of stress related products (e.g. carotenoids). This feedback control, along with the coordinated anti-sigma factor activity, is a well established regulation mechanism for transcriptional control used in bacteria. However, our results suggest that the multiply cycled bacteria may constitutively express higher levels of UsfY and by doing so they likely introduce positive gain into the system. At higher initial levels, UsfY is positioned to shift the equilibrium away from anti-sigF factors as they are produced. Stress signals that increase sigF levels (such as drying stress) would be rapidly amplified since any concomitantly produced anti-sigF factors would be immediately sequestered. In this way, multiply cycled bacteria can not only respond more robustly to stress stimuli but also faster. We feel the latter is an exceedingly important point as our spray drying procedure imposes an extreme change in environment over a very short timeframe.

The lack of differential expression of the UsfY cluster of genes in the dry powder further supports the idea that increased expression is more beneficial prior to the actual drying phase. In other words, strengthening of the cell wall, or accumulating a pool of antioxidants, or preparing for osmotic stresses, is best done proactively because once in the dry powder state energy may be required for 
other processes (such as repair). This postulate is evidenced by the overall transcriptional responses in dry powder. In the absence of "preparative" gene expression, the non-cycled bacteria appear to have increased expression of genes related to basic metabolic needs. This could reflect a slightly heightened response to the nutrient limited conditions, a last ditch effort to produce energy and acquire necessary components for maintenance, or an attempt at repair. In any case, the increased expression of these products appears to be insufficient (based on differences in viability) and too limited given the extreme urgency needed in adaptation to the harsh and resource-poor environment. In contrast, genes upregulated in the cycled bacteria suggest an attempt to cope with extreme stress with extreme measures. The increased expression of error-prone DNA polymerase IV, which provides a mechanism for adaptive mutagenesis, suggests this is the case while the number of transposases expressed indicates that dry powder environment is, in fact, catastrophic for the bacteria. Transposases facilitate the "jumping" of DNA segments randomly across genome in an effort to form new recombinant proteins to help combat a new stress. In our data we see that the IS1096 transposable element is highly and differentially expressed in cycled bacteria in the dry powder state. In addition, IS096 related transcripts (Appendix Table 8) include hypothetical proteins that have the IS1096 transposon partially overlapping on the complimentary strand. Transposons are known to contain complimentarily coded regulatory sequences (i.e. sigma factor binding sites) and the fact that these hypothetical proteins are being expressed in the dry powder state makes it highly likely that transposon mediated mutagenesis is in fact occurring. Our promoter analysis identified at least one copy of the IS096 TnpR transcript (MSMEG_4791) as being regulated by sigF and thus higher expression of IS096 in cycled bacteria is consistent with the cycled bacteria's UsfY augmented sigF response. Thus, "preparative" expression in cycled bacteria may be conferring an adaptive advantage in that an organism that can devote more energy and cellular resources to recombination, over one that has to scavenge more resources for maintenance and repair, has a substantially higher probability of surviving extreme duress.

In summary, our data suggests that the acquisition of enhanced cartenoid synthesis enhances post spray-drying dry powder viability. This enhanced synthesis could potentially result from a mutation in sigF or possibly from IS1096 transposition into regulatory sequences. Further work will be required to determine if the multiply spray dried phenotype, which we have designated MSDsigf $(+)$ (Table 1), and the high cartenoid phenotypes share a common mutation. In particular, sequencing of the sigF region of the chromosome will be of high priority.

Table 1. Strain Table.

\begin{tabular}{|c|l|l|}
\hline Strain Number & \multicolumn{1}{|c|}{ Description } & \multicolumn{1}{|c|}{ Origin } \\
\hline $\mathrm{mc}^{2} 155$ & High-frequency transformation mutant of ATCC 607 & $\begin{array}{l}\text { Bloom lab. } \\
\text { Snapper } \text { et al [27] }\end{array}$ \\
\hline MSDsigf $(+)$ & $\begin{array}{l}\text { Putative sigF regulatory mutant, with high carotenoid } \\
\text { content, isolated from multiply spray dried powders. }\end{array}$ & Edwards Lab \\
\hline
\end{tabular}




\section{Experimental Section}

\subsection{Culture and Growth Conditions}

M. smegmatis $\mathrm{mc}^{2} 155$ was generously provided by Dr. Barry Bloom of the Harvard School of Public Health. $\mathrm{Mc}^{2} 155$ was cultured in standard minimal media, Middlebrook $7 \mathrm{H} 9$ with 10\% OADC (BD Diagnostics, Rockville, MD), 0.2\% glycerol (Sigma, St Louis, MO), and $0.05 \%$ Tween 80 (Sigma), supplemented with $50 \mu \mathrm{g} / \mathrm{mL}$ hygromycin (Roche, Indianapolis, IN) and incubated at $37{ }^{\circ} \mathrm{C}$. Late exponential phase cultures were grown to an optical density (O.D.) of 1.3 ( $24 \mathrm{hrs})$. Stationary phase cultures were grown for three days to an O.D. > 3.0.

\subsection{Solution Preparation}

Spray drying solutions were prepared by pelleting cultures, washing them with $\mathrm{PBS} / 0.05 \%$ Tween 80 , and resuspending them in an equal volume of $0.05 \%$ Tyloxapol (Sigma). The final solution was mixed with an equal volume of $8 \mathrm{mg} / \mathrm{mL}$ L-leucine (Sigma) for a final concentration of $4 \mathrm{mg} / \mathrm{mL} \mathrm{L}$ leucine and $0.025 \%$ Tyloxapol. All solutions were used immediately after preparation.

\subsection{Spray Drying Conditions}

Spray drying was carried out in a Buchi B-290 mini spray dryer using a high performance cyclone and a $0.7 \mathrm{~mm}$ pressure nozzle tip (Buchi, Flawil, Switzerland). Solutions were spray dried at a feed rate of $7 \mathrm{~mL} / \mathrm{min}$ with a drying air flow rate of 35 liters/hr. Outlet temperature was kept between $42-45{ }^{\circ} \mathrm{C}$ by varying the inlet temperature from $115-125{ }^{\circ} \mathrm{C}$. The day-to-day variation was due to differences in ambient relative humidity. Powder was collected immediately and placed into amber scintillation vials. The vials were then stored in a desiccator placed in either a $40{ }^{\circ} \mathrm{C} / 75 \%$ or $25{ }^{\circ} \mathrm{C} /$ $60 \%$ relative humidity chamber.

\subsection{Viability}

Serial dilution plating followed by CFU determination was used to assess the number of viable $M$. smegmatis bacteria in cell suspensions before spray drying and in the powders post spray drying. Briefly, powders were resuspended in PBS/ $0.05 \%$ Tween 80 and vortexed to homogeneously disperse the samples. Samples were then serially diluted and placed on Middlebrook 7H10 agarose with 10\% OADC, $0.5 \%$ glycerol and supplemented with $50 \mu \mathrm{g} / \mathrm{mL}$ hygromycin. Plates, once inoculated, were wrapped in foil and incubated at $37{ }^{\circ} \mathrm{C}$ for three days. In order to assess the stability of the bacteria over time, powders were placed in storage conditions and plated at regular intervals.

\subsection{RNA Extraction}

RNA was extracted from either $25 \mathrm{~mL}$ of culture or $200 \mathrm{mg}$ of powder. Powder was first resuspended in $25 \mathrm{~mL}$ of DEPC water (Ambion, Austin, TX). Both solutions were then pelleted by centrifuging at 10,000 rpm for $1 \mathrm{~min}$. Extraction was then carried out as described in Managan et al. [28]. Briefly, $0.4 \mathrm{~mL}$ DEPC $\mathrm{H}_{2} \mathrm{O}$ and $1 \mathrm{~mL}$ of detergent solution (Tween-80, SDS (Sigma), 0.5M Sodium Acetate, DEPC $\mathrm{H}_{2} \mathrm{O}$ ) were added to the pellet and gently mixed. The mixture was added to $4 \mathrm{~mL}$ of 
$0.1 \mathrm{~mm}$ silica/ceramic beads in a $7 \mathrm{~mL}$ screw-top beadbeater tubes. Phenol: chloroform: isoamyl alcohol 125:24:1 (Sigma) and chloroform: isoamyl alcohol 24:1 (Sigma) were then added to the tubes. The mixture was bead beat on high for $45 \mathrm{sec}$ on a Biospec Mini-Bead Beater ${ }^{\mathrm{TM}}$. The broken cells were placed on ice for $10 \mathrm{~min}$. The liquid was transferred to $2 \mathrm{~mL}$ screw-capped tubes and centrifuged at $16 \mathrm{X} \mathrm{rpm}$ for $10 \mathrm{~min}$. The aqueous phase was removed and transferred to a fresh $2 \mathrm{~mL}$ screw-cap tube, equal volume chloroform isoamyl alcohol was then added. The solution was briefly centrifuged and the aqueous phase was once more removed. An equal volume of isopropanol solution was then added. Tubes were placed in $-80{ }^{\circ} \mathrm{C}$ freezer overnight. The tubes were centrifuged at $16 \mathrm{X} \mathrm{rpm}$ for $15 \mathrm{~min}$, the supernatant was poured off, and the pellet dried for $45 \mathrm{~min}$ on the bench top. RNA cleanup was carried out using a Qiagen RNeasy ${ }^{\circledR}$ Mini Kit with DNAse digestion. Total RNA was eluted in $60 \mu \mathrm{L}$ and concentration was determined on a NanoDrop ND-1000. RNA content was visually verified by running samples on precast agarose gels (Sigma) in a mini gel electrophoresis unit with ethidium bromide staining.

\section{6. cDNA Synthesis and Aminoallyl-labeling}

cDNA was synthesized by adding $2 \mu \mathrm{g}$ of total RNA to $2 \mu \mathrm{L}$ of random hexamers (Invitrogen, Grand Island, NY) and nuclease free water (Ambion) to achieve a final volume of $18.5 \mu \mathrm{L}$. Samples were incubated at $70{ }^{\circ} \mathrm{C}$ for 10 minutes, snap-frozen on ice and then centrifuged at $10,000 \mathrm{rpm}$. The solution was then added to $6 \mu \mathrm{L}$ first strand buffer (5X) (Invitrogen), $3 \mu \mathrm{L} 0.1 \mathrm{M}$ DTT, $0.6 \mu \mathrm{L} 25 \mathrm{mM}$ dNTP/aa-UTP labeling mix, and $2 \mu \mathrm{L}$ PowerScript RT (Invitrogen). The mixture was then incubated in a $42{ }^{\circ} \mathrm{C}$ water bath overnight. RNA was hydrolyzed by adding $10 \mu \mathrm{L} 0.5 \mathrm{M}$ EDTA (Ambion), $10 \mu \mathrm{L} 1 \mathrm{M} \mathrm{NaOH}$, and then incubating at $65{ }^{\circ} \mathrm{C}$ for 15 minutes. Next, $25 \mu \mathrm{L} 1 \mathrm{M}$ TRIS (pH 7.0) (Ambion) was added in order to neutralize the $\mathrm{pH}$. Unincorporated aa-DUTP and free amines were removed with a Qiagen MiniElute PCR purification kit. cDNA was eluted in $60 \mu \mathrm{L}$ and the concentration determined on a NanoDrop ND-1000. The cDNA was then dried in a speed vac. Samples were resuspended in $4.5 \mu \mathrm{L} 0.1 \mathrm{M}$ sodium carbonate buffer $\mathrm{pH} 9.3$ and added to $4.5 \mu \mathrm{L}$ of either Cy3 or Cy5 dye (Amersham). The solutions were allowed to incubate in the dark at room temperature for 1 hour. After coupling had finished, $35 \mu \mathrm{L}$ of $100 \mathrm{mM} \mathrm{NaOAc}$ pH 5.2 was added and the samples were purified using a Qiagen MiniElute PCR purification kit used according to the manufacturer instructions. Dye incorporation was assessed using the NanoDrop ND-1000 microarray analysis settings.

\subsection{Microarray Preparation and Hybridization}

M. smegmatis microarrays were generously provided by The Institute for Genomic Research (TIGR). Hybridization of labeled cDNA probes was carried out using the TIGR SOP M007/8. Briefly, microarray slides were incubated in a prehybridization solution at $42{ }^{\circ} \mathrm{C}$ in coplin jars for 1 hour. Slides were then transferred to a glass staining dish and washed $10 \mathrm{X}$ with $200 \mathrm{~mL}$ nuclease free water. The slides were then rinsed for $2 \mathrm{~min}$ in a staining dish filled with isopropyl alcohol and then centrifuged at $1000 \mathrm{rpm}$ for $10 \mathrm{~min}$ to dry. A 40\% formamide hybridization buffer was then prepared and $50 \mu \mathrm{L}$ was added to the cy3/cy5 probe. The probe mixture was placed on a $95{ }^{\circ} \mathrm{C}$ heat block for $5 \mathrm{~min}$, vortexed and then heated for another $5 \mathrm{~min}$. Prehybridized microarray slides were placed in a 
hybridization chamber with a clean LifterSlip (Erie Scientific, MA) and the probe mixture was added. A small amount of unused hybridization solution was added to each of the small wells located at either end of the microarray slide. The chamber was wrapped in foil and incubated in a $42{ }^{\circ} \mathrm{C}$ water bath overnight. After hybridization, slides were sequentially washed in $500 \mathrm{~mL}$ low stringency, medium stringency and high stringency buffers. Each wash step was carried out twice in glass staining dishes. Slides were rinsed briefly in $500 \mathrm{~mL}$ Millipore water and centrifuged for $2 \mathrm{~min}$ at $1000 \mathrm{rpm}$ and scanned.

\subsection{Image Scanning and Data Analysis}

Microarrays were scanned using an Axon scanner and data was acquired using Genepix Pro 5.1.0.19 software. Data was analyzed using Bioconductor bioinformatic software with the Limma statistical package [29]. Data was filtered to exclude poor spots (Flag $>-50$ ). Background was corrected using the backgroundCorrect command and data was normalized using the normalizeWithinArrays command. Adjusted data was then fit to linear and Bayesian models using the lmFit and eBayes commands. Intensity Ratios, Average Median Intensity and p-values were taken from the $\log \mathrm{FC}$, AveExpr, and the more stringent Adj. P.Val. in the output file and then averaged over the three gene replicates present on each microarray. Probability of Differential Expression was calculated using the Limma log-odds score (B) and equation (1).

$$
\left(\frac{e^{(B)}}{1+e^{(B)}}\right) \times 100
$$

\section{Conclusions}

Our results suggest that relevant stressing of bacteria, such as M. smegmatis, can lead to highly stable dry powder formulations with remarkable room temperature stability characteristics. Repeated spray drying and selective pressures in dry powders may enrich for strains which can persist in harsh conditions. It is likely we have selected a natural population most fit for long term survival in dry powders which in theory could make for more stable vaccines. However, it is clear that the dry powder state is exceedingly harsh and may induce recombination events. In applying our methodology to more relevant vaccine strains it will be important to ensure they retain immunogenicity and remain safe.

We have demonstrated a new approach useful in the formulation of live whole-cell vaccines. This approach centers on the biochemistry of the organism rather than the chemical and physical parameters often the focus of vaccine formulation efforts. The approach has not only provided insight into mechanisms that influence viability, but has also led us to specific compounds that may prove advantageous in the dry powder formulation of other important organisms.

\section{Acknowledgements}

This work was supported by a Grand Challenge in Global Health grant to DE from the Bill and Melinda Gates Foundation. 


\section{References and Notes}

1. Milstien, J.B.; Gibson, J.J. Quality control of BCG vaccine by WHO: A review of factors that my influence vaccine effectiveness and safety. Bull. WHO 1990, 68, 93-108.

2. Smith, K.C.; Stakre, J.R. Bacille Calmette-Guerin Vaccine. In Vaccines, 4th ed.; Plotkin, S.A., Orenstein, W.A., Eds.; Saunders: Philadelphia, PA, USA, 2004; Volume xxi, p. 111.

3. Plotkin, S.A.; Orenstein, W.A. Vaccines, 4th Ed.; Saunders: Philadelphia, PA, 2004; Volume xxi, pp. 1662.

4. Lind, A. Stability of dried BCG stored at $-70{ }^{\circ} \mathrm{C},-25^{\circ} \mathrm{C}$ and $+4{ }^{\circ} \mathrm{C}$. Scand. J. Respir. Dis. 1967, 48, 343-347.

5. Devadoss, P.; Klegerman, M.; Groves, M. A scanning electron microscope study of mycobacterial development stages in commercial BCG vaccines. Curr. Nicrobiol. 1991, 22, 247-252.

6. Wong, Y.L.; Sampson, S.; Germishuizen, W.A.; Goonesekera, S.; Caponetti, G.; Sadoff, J.; Bloom, B.R.; Edwards, D. Drying a tuberculosis vaccine without freezing. Pro. Natl. Acad. Sci. USA 2007, 104, 2591-2595.

7. Smeulders, M.J.; Keer, J.; Speight, R.A.; Williams, H.D. Adaptation of Mycobacterium smegmatis to stationary phase. J. Bacteriol. 1999, 181, 270-283.

8. Gebhard, S.; Humpel, A.; McLellan, A.D.; Cook, G.M. The alternative sigma factor SigF of Mycobacterium smegmatis is required for survival of heat shock, acidic $\mathrm{pH}$ and oxidative stress. Microbiology 2008, 154, 2786-2795.

9. Wigneshweraraj, S.; Bose, D.; Burrows, P.C.; Joly, N.; Schumacher, J.; Rappas, M.; Pape, T.; Zhang, X.; Stockley, P.; Severinov, K.; Buck, M. Modus operandi of the bacterial RNA polymerase containing the sigma54 promoter-specificity factor. Mol. Microbiol. 2008, 68, 538-46.

10. Calamita, H.; Ko, C.; Tyagi, S.; Yoshimatsu, T.; Morrison, N.E.; Bishai, W.R. The Mycobacterium tuberculosis SigD sigma factor controls the expression of ribosome-associated gene products in stationary phase and is required for full virulence. Cell Microbiol. 2005, 7, 233-244.

11. Gadagkar, R.; Gopinathan, K.P. Growth of Mycobacterium smegmatis in minimal and complete media. J. Biosci. 1980, 2, 337-348.

12. Salazar, L.; Fsihi, H.; de Rossi, E.; Riccardi, G.; Rios, C.; Cole, S.T.; Takiff, H.E. Organization of the origins of replication of the chromosomes of Mycobacterium smegmatis, Mycobacterium leprae and Mycobacterium tuberculosis and isolation of a functional origin from M. smegmatis. Mol. Microbiol. 2006, 20, 283-293.

13. Manca, C.; Paul, S.; Barry, C.E.; Freedman, V.H.; Kaplan, G. Mycobacterium tuberculosis catalase and peroxidase activities and resistance to oxidative killing in human monocytes in vitro. Infect. Immun. 1999, 67, 74-79.

14. Nakano, M.M.; Hoffmann, T.; Zhu, Y.; Jahn, D. Nitrogen and oxygen regulation of bacillus subtilis nasDEF encoding NADH-dependent nitrite reductase by TnrA and ResDE. J. Bacteriol. 1998, 180, 5344-5350. 
15. Kazmierczak, M.J.; Wiedmann, M.; Boor, K.J. Alternative sigma factors and their roles in bacterial virulence. Microbiol. Mol. Biol. Rev. 2005, 69, 527-543.

16. Horsburgh, M.J.; Wiltshire, M.D.; Crossley, H.; Ingham, E.; Foster, S.J. PheP, a putative amino acid permease of Staphylococcus aureus, contributes to survival in vivo and during starvation. Infect. Immun. 2004, 72, 3073-3076.

17. Berney, M.; Cook, G. Unique flexibility in energy metabolism allows mycobacteria to combat starvation and hypoxia. PloS ONE 2010, 5, e8614.

18. Dube, D.; Tripathi, S.; Ramachandran, R. Identification of in vitro inhibitors of Mycobacterium tuberculosis Lysine $\varepsilon$-aminotransferase by pharmacophore mapping and three-dimensional flexible searches. Med. Chem. Res. 2008, 17, 182-188.

19. Gupta, S.; Chatterji, D. Bimodal protection of DNA by Mycobacterium smegmatis DNA-binding protein from stationary phase cells. J. Biol. Chem. 2003, 278, 5235-5241.

20. Cirillo, J.D.; Barletta, R.G.; Bloom, B.R.; Jacobs, W.R. A novel transposon trap for mycobacteria: Isolation and characterization of IS1096. J. Bacteriol. 1991, 173, 7772-7780.

21. Provvedi, R.; Kocincova, D.; Dona, V.; Euphrasie, D.; Daffe, M.; Etienne, G.; Manganelli, R.; Reyrat, J-M. SigF controls carotenoid pigment production and affects transformation efficiency and hydrogen peroxide sensitivity in Mycobacterium smegmatis. J. Bacteriol. 2008, 190, 7859-7863.

22. Kubler, O.; Baumeister, W. The structure of a periodic cell wall component (HPI-layer of Micrococcus radiodurans). Cytobiologie 1978, 17, 1-9.

23. Snapper, S.B.; Lugosi, L.; Jekkel, A.; Melton, R.E.; Kieser, T.; Bloom, B.R.; Jacobs, W.R. Lysogeny and transformation in mycobacteria: Stable expression of foreign genes. Pro. Natl. Acad. Sci. USA 1988, 85, 6987-6991.

24. Hermans, J.; Bont, J.A.M. The study of mycobacterial genetics has experienced quick technical developments. Anton. Leeuw. 1996, 69, 243-256.

25. DeMaio, J.; Zhang, Y.; Ko, C.; Bishal, W.R. Mycobacterium tuberculosis sigF is part of a gene cluster with similarities to the Bacillus subtilis sigF and sigB operons. Tubercle Lung Dis. 1997, $78,3-12$.

26. Chen, J.; Demaio, J.; Bishai, W.R. A possible antisigma factor in a sigF-containing gene cluster of Mycobacterium tuberculosis. Abstr. Gen. Meet. Am. Soc. Microbiol. 1997, Abstract Number U133, 566.

27. Snapper, S.B.; Melton, R.E.; Mustafa, S.; Kieser, T.; Jacob, W.R., Jr. Isolation and characterization of efficient plasmid transformation mutants of Mycobacterium smegmatis. Mol. Microbiol. 1990, 4, 1911-1919.

28. Mangan, J.A.; Sole, K.M.; Mitchison, D.A.; Butcher, P.D. An effective method of RNA extraction from bacteria refractory to disruption, including mycobacteria. Nucleic Acids Res. 1997, 25, 675-676.

29. Smyth, G.K. Limma: Linear models for microarray data. In Bioinformatics and Computational Biology Solutions Using R and Bioconductor; Gentleman, R., Carey, V., Dudoit, S., Irizarry, R., Huber, W., Eds.; Springer: New York, NY, USA, 2005; pp. 397-420. 


\section{Appendix Tables-Microarray Data}

Appendix Table 1. Ribosomal genes up-regulated in log phase (non-spray dried log versus stationary comparison).

\begin{tabular}{|c|c|c|c|c|c|c|}
\hline Primary Target & Common Name & Gene & $\begin{array}{l}\text { Intensit } \\
\text { y Ratio }\end{array}$ & $\begin{array}{l}\text { Average } \\
\text { Channel } \\
\text { Intensity }\end{array}$ & $\begin{array}{c}\mathrm{p}- \\
\text { value }\end{array}$ & $\begin{array}{l}\text { Probability } \\
\text { of } \\
\text { Differential } \\
\text { Expression }\end{array}$ \\
\hline MSMEG_1347 & ribosomal protein L1 & rplA & 1.4 & 11.8 & 0.001 & $88 \%$ \\
\hline MSMEG_1439 & ribosomal protein L2 & rplB & 1.3 & 12.6 & 0.001 & $81 \%$ \\
\hline MSMEG_1436 & ribosomal protein L3 & $\mathrm{rplC}$ & 1.2 & 11.4 & 0.001 & $97 \%$ \\
\hline MSMEG_1437 & $\begin{array}{c}\text { ribosomal protein } \mathrm{L} 4 / \mathrm{L} 1 \\
\text { family protein }\end{array}$ & rplD & 1.3 & 12.1 & 0.000 & $99 \%$ \\
\hline MSMEG_1467 & ribosomal protein L5 & & 1.8 & 11.8 & 0.000 & $100 \%$ \\
\hline MSMEG_1470 & ribosomal protein L6 & & 1.2 & 12.6 & 0.001 & $94 \%$ \\
\hline MSMEG_6894 & ribosomal protein L9 & rplI & 1.0 & 11.3 & 0.001 & $89 \%$ \\
\hline MSMEG_1364 & ribosomal protein L10 & & 2.1 & 12.7 & 0.000 & $99 \%$ \\
\hline MSMEG_1346 & ribosomal protein L11 & rplK & 1.5 & 13.1 & 0.000 & $99 \%$ \\
\hline MSMEG_1365 & ribosomal protein L7/L12 & rplL & 2.8 & 11.9 & 0.001 & $95 \%$ \\
\hline MSMEG_1556 & ribosomal protein L13 & rplM & 1.8 & 13.5 & 0.002 & $65 \%$ \\
\hline MSMEG_1465 & ribosomal protein L14 & rplN & 1.1 & 11.3 & 0.004 & $55 \%$ \\
\hline MSMEG_1474 & ribosomal protein L15 & $\mathrm{rplO}$ & 1.3 & 11.8 & 0.002 & $77 \%$ \\
\hline MSMEG_1443 & ribosomal protein L16 & rplP & 1.8 & 13.0 & 0.001 & $95 \%$ \\
\hline MSMEG_1525 & ribosomal protein L17 & & 1.1 & 12.3 & 0.003 & $59 \%$ \\
\hline MSMEG_1471 & ribosomal protein L18 & rplR & 1.6 & 12.2 & 0.000 & $98 \%$ \\
\hline MSMEG_2440 & ribosomal protein L19 & rplS & 1.2 & 11.4 & 0.001 & $92 \%$ \\
\hline MSMEG_3791 & ribosomal protein L20 & rplT & 0.6 & 12.1 & 0.010 & $17 \%$ \\
\hline MSMEG_4625 & ribosomal protein L21 & rplU & 1.3 & 12.9 & 0.001 & $96 \%$ \\
\hline MSMEG_1441 & ribosomal protein L22 & & 1.5 & 11.1 & 0.006 & $33 \%$ \\
\hline MSMEG_1438 & ribosomal protein L23 & rplW & 1.4 & 12.1 & 0.000 & $98 \%$ \\
\hline MSMEG_1466 & ribosomal protein L24 & $\mathrm{rplX}$ & 1.1 & 12.0 & 0.001 & $96 \%$ \\
\hline MSMEG_5431 & $\begin{array}{l}\text { ribosomal protein L25, } \\
\text { Ctc-form }\end{array}$ & & 1.9 & 11.3 & 0.000 & $99 \%$ \\
\hline MSMEG_4624 & ribosomal protein L27 & rpmA & 0.2 & 12.9 & 0.324 & $0 \%$ \\
\hline MSMEG_6068 & ribosomal protein L28 & rpmB & 0.1 & 9.8 & 0.734 & $0 \%$ \\
\hline MSMEG_2400 & ribosomal protein L28 & $\mathrm{rpmB}$ & 1.5 & 12.8 & 0.000 & $99 \%$ \\
\hline MSMEG_1444 & ribosomal protein L29 & rpmC & 1.8 & 11.8 & 0.013 & $14 \%$ \\
\hline MSMEG_1473 & ribosomal protein L30 & rpmD & 1.5 & 11.9 & 0.001 & $95 \%$ \\
\hline MSMEG_4951 & ribosomal protein L31 & rpmE & 0.8 & 13.8 & 0.005 & $37 \%$ \\
\hline MSMEG_5489 & ribosomal protein L32 & $\mathrm{rpmF}$ & 1.1 & 11.1 & 0.010 & $22 \%$ \\
\hline MSMEG_6070 & ribosomal protein L31 & rpmE & 0.0 & 10.1 & 0.704 & $0 \%$ \\
\hline MSMEG_6067 & ribosomal protein L33 & rpmG & -0.4 & 9.4 & 0.368 & $0 \%$ \\
\hline MSMEG_1339 & ribosomal protein L33 & rpmG & 0.6 & 11.6 & 0.045 & $9 \%$ \\
\hline MSMEG_6946 & ribosomal protein L34 & $\mathrm{rpmH}$ & 0.3 & 11.5 & 0.282 & $0 \%$ \\
\hline
\end{tabular}


Appendix Table 1. Cont.

\begin{tabular}{|c|c|c|c|c|c|c|}
\hline Primary Target & Common Name & Gene & $\begin{array}{l}\text { Intensit } \\
\text { y Ratio }\end{array}$ & $\begin{array}{l}\text { Average } \\
\text { Channel } \\
\text { Intensity }\end{array}$ & $\begin{array}{c}\mathrm{p}- \\
\text { value }\end{array}$ & $\begin{array}{c}\text { Probability } \\
\text { of } \\
\text { Differential } \\
\text { Expression }\end{array}$ \\
\hline MSMEG_3792 & ribosomal protein L35 & $\mathrm{rpmI}$ & 0.8 & 13.6 & 0.004 & $46 \%$ \\
\hline MSMEG_1520 & ribosomal protein L36 & rpmJ & 0.4 & 13.3 & 0.080 & $1 \%$ \\
\hline MSMEG 3833 & ribosomal protein $\mathrm{S} 1$ & & -0.3 & 12.1 & 0.174 & $1 \%$ \\
\hline MSMEG_2519 & ribosomal protein $\mathrm{S} 2$ & $\mathrm{rpsB}$ & 2.0 & 11.7 & 0.000 & $100 \%$ \\
\hline MSMEG_1442 & ribosomal protein $\mathrm{S} 3$ & $\mathrm{rpsC}$ & 1.8 & 11.8 & 0.000 & $99 \%$ \\
\hline MSMEG_1523 & ribosomal protein $\mathrm{S} 4$ & $\mathrm{rpsD}$ & 1.0 & 12.0 & 0.002 & $68 \%$ \\
\hline MSMEG_1472 & ribosomal protein $\mathrm{S} 5$ & $\mathrm{rpsE}$ & 1.4 & 12.2 & 0.001 & $93 \%$ \\
\hline MSMEG_6897 & ribosomal protein S6 & $\mathrm{rpsF}$ & 2.9 & 11.6 & 0.000 & $100 \%$ \\
\hline MSMEG_1399 & ribosomal protein $\mathrm{S} 7$ & rpsG & 1.9 & 12.7 & 0.000 & $100 \%$ \\
\hline MSMEG_1469 & ribosomal protein $\mathrm{S} 8$ & $\mathrm{rpsH}$ & 1.8 & 12.4 & 0.001 & $93 \%$ \\
\hline MSMEG_1557 & ribosomal protein S9 & rpsI & 1.1 & 12.7 & 0.001 & $90 \%$ \\
\hline MSMEG_1435 & ribosomal protein $\mathrm{S} 10$ & rpsJ & 1.1 & 12.3 & 0.001 & $88 \%$ \\
\hline MSMEG_1522 & ribosomal protein S11 & rpsK & 1.2 & 12.8 & 0.001 & $88 \%$ \\
\hline MSMEG_1398 & ribosomal protein $\mathrm{S} 12$ & rpsL & 1.4 & 12.4 & 0.001 & $97 \%$ \\
\hline MSMEG_6066 & ribosomal protein S14 & & -0.6 & 9.0 & 0.255 & $0 \%$ \\
\hline MSMEG_1468 & $\begin{array}{c}\text { ribosomal protein } \\
\mathrm{S} 14 \mathrm{p} / \mathrm{S} 29 \mathrm{e}\end{array}$ & $\operatorname{rpsN}$ & 1.6 & 12.1 & 0.003 & $60 \%$ \\
\hline MSMEG_1521 & $\begin{array}{c}\text { ribosomal protein } \\
\mathrm{S} 13 \mathrm{p} / \mathrm{S} 18 \mathrm{e} \\
\end{array}$ & $\mathrm{rpsM}$ & 0.9 & 12.3 & 0.014 & $12 \%$ \\
\hline MSMEG_2654 & ribosomal protein S15 & $\mathrm{rpsO}$ & 1.3 & 11.4 & 0.001 & $92 \%$ \\
\hline MSMEG_2435 & ribosomal protein $\mathrm{S} 16$ & & 1.8 & 11.1 & 0.003 & $68 \%$ \\
\hline MSMEG_1445 & ribosomal protein S17 & & 2.0 & 12.2 & 0.001 & $91 \%$ \\
\hline MSMEG_6065 & ribosomal protein S18 & rpsR & -0.3 & 9.3 & 0.587 & $0 \%$ \\
\hline MSMEG_6895 & ribosomal protein S18 & rpsR & 1.4 & 12.2 & 0.001 & $88 \%$ \\
\hline MSMEG_1440 & ribosomal protein S19 & $\mathrm{rpsS}$ & 1.4 & 12.1 & 0.001 & $97 \%$ \\
\hline MSMEG_4571 & ribosomal protein S20 & rpsT & 0.5 & 12.1 & 0.033 & $4 \%$ \\
\hline
\end{tabular}


Appendix Table 2. Select up-regulated operons and clusters in log phase over stationary phase (non-spray dried log versus stationary comparision).

\begin{tabular}{|c|c|c|c|c|c|c|}
\hline Primary Target & Common Name & Gene & $\begin{array}{l}\text { Intensity } \\
\text { Ratio }\end{array}$ & $\begin{array}{l}\text { Average } \\
\text { Channel } \\
\text { Intensity }\end{array}$ & $\mathrm{p}$-value & $\begin{array}{l}\text { Probability of } \\
\text { Differential } \\
\text { Expression }\end{array}$ \\
\hline \multicolumn{7}{|c|}{ Electron transport } \\
\hline MSMEG_4939 & ATP synthase delta chain & & 1.5 & 11.9 & 0.00 & $98 \%$ \\
\hline MSMEG_4942 & ATP synthase F0, A subunit & atpB & 1.3 & 11.5 & 0.00 & $88 \%$ \\
\hline MSMEG_4941 & ATP synthase F0, C subunit & atpE & 1.8 & 13.3 & 0.00 & $99 \%$ \\
\hline MSMEG_4938 & ATP synthase F1, alpha subunit & atpA & 1.5 & 11.7 & 0.00 & $99 \%$ \\
\hline MSMEG_4936 & ATP synthase F1, beta subunit & atpD & 1.5 & 12 & 0.00 & $99 \%$ \\
\hline MSMEG_4935 & ATP synthase F1, epsilon subunit & atpC & 0.7 & 10.9 & 0.03 & $5 \%$ \\
\hline MSMEG_4937 & ATP synthase F1, gamma subunit & atpG & 1.7 & 11.4 & 0.00 & $100 \%$ \\
\hline MSMEG_4268 & cytochrome c oxidase subunit 2 & & 1.7 & 12.6 & 0.00 & $99 \%$ \\
\hline MSMEG_2352 & electron transfer flavoprotein, alpha subunit & etfA & 1.7 & 11.9 & 0.00 & $100 \%$ \\
\hline MSMEG_4527 & ferredoxin sulfite reductase & & 1.8 & 11.4 & 0.00 & $100 \%$ \\
\hline MSMEG_4261 & $\begin{array}{l}\text { ubiquinol-cytochrome c reductase cytochrome c } \\
\text { subunit }\end{array}$ & & 1.5 & 12.9 & 0.00 & $99 \%$ \\
\hline MSMEG_4262 & ubiquinol-cytochrome c reductase iron-sulfur subunit & & 1.5 & 13.5 & 0.00 & $99 \%$ \\
\hline \multicolumn{7}{|c|}{ Energy Metabolism } \\
\hline MSMEG_5672 & citrate synthase I & gltA & 1.4 & 12.2 & 0.00 & $99 \%$ \\
\hline MSMEG_5415 & enolase & eno & 1.8 & 12.2 & 0.00 & $100 \%$ \\
\hline MSMEG_3084 & glyceraldehyde-3-phosphate dehydrogenase, type I & gap & 1.9 & 12.1 & 0.00 & $100 \%$ \\
\hline MSMEG_1654 & isocitrate dehydrogenase, NADP-dependent & & 1.8 & 11.8 & 0.00 & $98 \%$ \\
\hline MSMEG_3200 & L-aspartate oxidase & nadB & 1.9 & 10 & 0.00 & $100 \%$ \\
\hline
\end{tabular}


Appendix Table 2. Cont.

\begin{tabular}{|c|c|c|c|c|c|c|}
\hline Primary Target & Common Name & Gene & $\begin{array}{l}\text { Intensity } \\
\text { Ratio }\end{array}$ & $\begin{array}{l}\text { Average } \\
\text { Channel } \\
\text { Intensity }\end{array}$ & p-value & $\begin{array}{l}\text { Probability of } \\
\text { Differential } \\
\text { Expression }\end{array}$ \\
\hline MSMEG_3085 & phosphoglycerate kinase & pgk & 1.5 & 11.3 & 0.00 & $97 \%$ \\
\hline MSMEG_3227 & pyruvate kinase & pyk & 1.2 & 11.7 & 0.00 & $95 \%$ \\
\hline MSMEG_3199 & quinolinate synthetase complex, A subunit & $\operatorname{nadA}$ & 1.7 & 11 & 0.00 & $97 \%$ \\
\hline MSMEG_0932 & ROK family protein & & 2.1 & 11.2 & 0.00 & $100 \%$ \\
\hline MSMEG_5524 & succinyl-CoA synthetase, alpha subunit & sucD & 1.6 & 10.6 & 0.00 & $99 \%$ \\
\hline MSMEG_5525 & succinyl-CoA synthetase, beta subunit & sucC & 1.6 & 10.8 & 0.00 & $99 \%$ \\
\hline \multicolumn{7}{|l|}{ Protein Folding } \\
\hline MSMEG_0880 & chaperonin GroL & groL & 2.5 & 13.6 & 0.00 & $93 \%$ \\
\hline MSMEG_1583 & chaperonin GroL & groL & 2 & 11.4 & 0.00 & $100 \%$ \\
\hline MSMEG_1582 & chaperonin GroS & groS & 2.1 & 12.4 & 0.00 & $100 \%$ \\
\hline MSMEG_0024 & peptidyl-prolyl cis-trans isomerase B & & 3.3 & 13.5 & 0.00 & $100 \%$ \\
\hline MSMEG_2974 & peptidyl-prolyl cis-trans isomerase, cyclophilin-type & & 1.2 & 11 & 0.00 & $83 \%$ \\
\hline MSMEG_3434 & \multicolumn{2}{|c|}{ peptidyl-prolyl cis-trans isomerase, fkbp-type domain protein } & 1.1 & 10.7 & 0.00 & $83 \%$ \\
\hline \multicolumn{7}{|c|}{ Lipiid Metabolism } \\
\hline MSMEG_4326 & acyl carrier protein & acpP & 1.5 & 13.2 & 0.00 & $95 \%$ \\
\hline MSMEG_5248 & acyl-[ACP] desaturase & & 1.7 & 10.5 & 0.00 & $88 \%$ \\
\hline MSMEG_2131 & acyl-CoA synthase & & 1.5 & 10.1 & 0.00 & $94 \%$ \\
\hline MSMEG_5273 & beta-ketoadipyl CoA thiolase & & 1.5 & 11.6 & 0.00 & $99 \%$ \\
\hline MSMEG_5773 & fatty acid desaturase & & 1.4 & 11.4 & 0.00 & $92 \%$ \\
\hline MSMEG_4351 & hypothetical oxidoreductase YjgI & & 1.8 & 10.3 & 0.00 & $60 \%$ \\
\hline MSMEG_0096 & peroxisomal hydratase-dehydrogenase-epimerase & & 2.3 & 11 & 0.00 & $100 \%$ \\
\hline
\end{tabular}


Appendix Table 2. Cont.

\begin{tabular}{|c|c|c|c|c|c|c|}
\hline Primary Target & Common Name & Gene & $\begin{array}{l}\text { Intensity } \\
\text { Ratio }\end{array}$ & $\begin{array}{l}\text { Average } \\
\text { Channel } \\
\text { Intensity }\end{array}$ & p-value & $\begin{array}{l}\text { Probability of } \\
\text { Differential } \\
\text { Expression }\end{array}$ \\
\hline \multicolumn{7}{|c|}{ Maintenance and Growth } \\
\hline MSMEG_1843 & adenosylhomocysteinase & ahcY & 1.8 & 11.1 & 0.00 & $99 \%$ \\
\hline MSMEG_1540 & ATP-dependent RNA helicase & & 1.6 & 11 & 0.00 & $91 \%$ \\
\hline MSMEG_6403 & bifunctional udp-galactofuranosyl transferase glft & & 1.6 & 11.1 & 0.00 & $95 \%$ \\
\hline MSMEG_1947 & conserved hypothetical protein [(glutaredoxin)] & & 1.8 & 12.2 & 0.00 & $88 \%$ \\
\hline MSMEG_4396 & isochorismatase hydrolase & & 1.7 & 10 & 0.00 & $100 \%$ \\
\hline MSMEG_6896 & single-stranded DNA-binding protein & & 2.1 & 11.6 & 0.00 & $100 \%$ \\
\hline MSMEG_4891 & alkylhydroperoxide reductase & & 1.8 & 12.9 & 0.00 & $100 \%$ \\
\hline MSMEG_0835 & copper/zinc superoxide dismutase & sodC & 1.6 & 11.9 & 0.00 & $97 \%$ \\
\hline MSMEG_0314 & glucose-6-phosphate 1-dehydrogenase & zwf & 1.3 & 11 & 0.00 & $92 \%$ \\
\hline MSMEG_4557 & $\mathrm{ABC}$ transporter, ATP-binding protein & & 1.7 & 10.4 & 0.00 & $100 \%$ \\
\hline MSMEG 4560 & periplasmic binding protein & & 1.9 & 10.8 & 0.00 & $99 \%$ \\
\hline MSMEG_4561 & \multicolumn{2}{|c|}{$\mathrm{ABC} \mathrm{Fe} 3+$-siderophores transporter, periplasmic binding protein } & 1.7 & 9.7 & 0.00 & $94 \%$ \\
\hline MSMEG_4533 & sulfate-binding protein & & 1.7 & 10.5 & 0.00 & $90 \%$ \\
\hline MSMEG_5788 & integral membrane protein & & 1.6 & 10.4 & 0.00 & $98 \%$ \\
\hline MSMEG_5789 & putative thiosulfate sulfurtransferase & & 3.2 & 11.9 & 0.00 & $100 \%$ \\
\hline MSMEG_5790 & SseC protein & & 3.5 & 12.6 & 0.00 & $100 \%$ \\
\hline
\end{tabular}


Appendix Table 3. Select up-regulated operons and clusters in stationary phase over log phase (non-spray dried log versus stationary comparision).

\begin{tabular}{|c|c|c|c|c|c|c|}
\hline Primary Target & Common Name & Gene & $\begin{array}{l}\text { Intensity } \\
\text { Ratio }\end{array}$ & $\begin{array}{l}\text { Average Channel } \\
\text { Intensity }\end{array}$ & p-value & $\begin{array}{l}\text { Probability of } \\
\text { Differential } \\
\text { Expression }\end{array}$ \\
\hline \multicolumn{7}{|c|}{ Carbon Limitation } \\
\hline MSMEG_1552 & ethanolamine permease & eat & 1.5 & 12.7 & 0.00 & $72 \%$ \\
\hline MSMEG_1553 & ethanolamine ammonia-lyase, large subunit & eutB & 2.3 & 11.6 & 0.00 & $95 \%$ \\
\hline MSMEG_1554 & ethanolamine ammonia-lyase, light chain & eutC & 2.4 & 10.5 & 0.00 & $99 \%$ \\
\hline MSMEG_1970 & sigma factor & & 4.2 & 11.6 & 0.00 & $99 \%$ \\
\hline MSMEG_1971 & propane monooxygenase hydroxylase large subunit & & 3.5 & 11.1 & 0.00 & $99 \%$ \\
\hline MSMEG_1973 & propane monooxygenase hydroxylase small subunit & & 2.1 & 10.6 & 0.00 & $98 \%$ \\
\hline MSMEG_1972 & methane monooxygenase component $\mathrm{C}$ & & 1.4 & 9.9 & 0.00 & $82 \%$ \\
\hline MSMEG_1974 & propane monooxygenase coupling protein & & 2.0 & 10.9 & 0.00 & $99 \%$ \\
\hline MSMEG_1975 & amidohydrolase 2 & & 2.3 & 10.8 & 0.00 & $97 \%$ \\
\hline MSMEG_1976 & conserved hypothetical protein & & 2.4 & 10.2 & 0.00 & $100 \%$ \\
\hline MSMEG_1977 & alcohol dehydrogenase & & 1.7 & 10.5 & 0.00 & $94 \%$ \\
\hline MSMEG_1978 & chaperonin GroL & groL & 2.0 & 10.5 & 0.00 & $89 \%$ \\
\hline MSMEG_1979 & antibiotic biosynthesis monooxygenase & & 1.3 & 11.4 & 0.00 & $99 \%$ \\
\hline MSMEG_4206 & Molybdopterin oxidoreductase & & 3.1 & 10.8 & 0.00 & $98 \%$ \\
\hline MSMEG_4207 & universal stress protein family protein & & 3.1 & 11.9 & 0.00 & $99 \%$ \\
\hline MSMEG_4208 & integral membrane protein & & 4.2 & 12.3 & 0.00 & $100 \%$ \\
\hline MSMEG_4209 & integral membrane protein & & 3.8 & 11.4 & 0.00 & $99 \%$ \\
\hline MSMEG_4210 & secreted protein & & 4.9 & 11.6 & 0.00 & $100 \%$ \\
\hline \multicolumn{7}{|c|}{ Scavenging Pathways } \\
\hline MSMEG_1411 & universal stress protein family protein & & 1.3 & 10.3 & 0.00 & $85 \%$ \\
\hline MSMEG_1412 & amino acid permease & & 1.3 & 11.0 & 0.00 & $91 \%$ \\
\hline MSMEG_1413 & ornithine--oxo-acid transaminase & rocD & 2.3 & 10.9 & 0.00 & $94 \%$ \\
\hline MSMEG_1414 & Amidinotransferase & & 2.0 & 11.3 & 0.00 & $97 \%$ \\
\hline MSMEG_1417 & glyoxalase family protein & & 1.0 & 9.9 & 0.00 & $65 \%$ \\
\hline
\end{tabular}


Appendix Table 3. Cont.

\begin{tabular}{|c|c|c|c|c|c|c|}
\hline Primary Target & Common Name & Gene & $\begin{array}{l}\text { Intensity } \\
\text { Ratio }\end{array}$ & $\begin{array}{l}\text { Average Channel } \\
\text { Intensity }\end{array}$ & p-value & $\begin{array}{l}\text { Probability of } \\
\text { Differential } \\
\text { Expression }\end{array}$ \\
\hline MSMEG_1418 & RNA polymerase ECF-type sigma factor & & 0.8 & 10.7 & 0.00 & $67 \%$ \\
\hline MSMEG_5117 & proline dehydrogenase & & 2.9 & 11.7 & 0.00 & $100 \%$ \\
\hline MSMEG 5119 & 1-pyrroline-5-carboxylate dehydrogenase & pruA & 2.8 & 12.0 & 0.00 & $100 \%$ \\
\hline MSMEG_2748 & soluble pyridine nucleotide transhydrogenase & sthA & 2.4 & 10.8 & 0.00 & $99 \%$ \\
\hline \multicolumn{7}{|c|}{ Membrane and Cell Wall Synthesis } \\
\hline MSMEG_2522 & efflux $\mathrm{ABC}$ transporter, permease protein & & 1.6 & 12.0 & 0.00 & $98 \%$ \\
\hline MSMEG_2523 & efflux $\mathrm{ABC}$ transporter, permease protein, putative & & 3.1 & 11.0 & 0.00 & $99 \%$ \\
\hline MSMEG_2524 & $\mathrm{ABC}$ transporter, ATP-binding protein & & 3.8 & 10.9 & 0.00 & $100 \%$ \\
\hline MSMEG_2525 & amino acid permease superfamily protein & & 4.7 & 12.1 & 0.00 & $99 \%$ \\
\hline MSMEG_2526 & copper methylamine oxidase & & 3.2 & 12.1 & 0.00 & $100 \%$ \\
\hline \multicolumn{7}{|c|}{ Oxygen Limitation } \\
\hline MSMEG_2270 & hypothetical protein & & 1.1 & 10.8 & 0.00 & $80 \%$ \\
\hline MSMEG 2271 & hydrogenase accessory protein HypB & hypB & 0.8 & 11.5 & 0.00 & $67 \%$ \\
\hline MSMEG_2272 & hydrogenase nickel insertion protein HypA & hypA & 1.0 & 11.4 & 0.00 & $87 \%$ \\
\hline MSMEG 2273 & {$[\mathrm{NiFe}]$ hydrogenase maturation protein $\mathrm{HypF}$} & hypF & 1.6 & 10.6 & 0.00 & $92 \%$ \\
\hline MSMEG_2274 & hydrogenase assembly chaperone HypC/HupF & hypC & 1.2 & 12.3 & 0.00 & $95 \%$ \\
\hline MSMEG 2276 & hydrogenase expression/formation protein HypE & hypE & 0.7 & 14.0 & 0.01 & $34 \%$ \\
\hline MSMEG_2702 & hydrogenase expression/formation protein HypD & hypD & 1.3 & 10.7 & 0.00 & $90 \%$ \\
\hline MSMEG 2703 & hydrogenase assembly chaperone $\mathrm{HypC} / \mathrm{HupF}$ & hypC & 1.5 & 10.3 & 0.00 & $99 \%$ \\
\hline MSMEG_2705 & hydrogenase expression/formation protein HypE & hypE & 1.5 & 10.2 & 0.00 & $90 \%$ \\
\hline MSMEG_2706 & phosphoheptose isomerase & gmhA & 2.5 & 10.3 & 0.00 & $100 \%$ \\
\hline MSMEG_2711 & [NiFe] hydrogenase maturation protein $\mathrm{HypF}$ & hypF & 1.6 & 10.2 & 0.00 & $98 \%$ \\
\hline MSMEG_2712 & hydrogenase assembly chaperone $\mathrm{HypC} / \mathrm{HupF}$ & hypC & 1.7 & 10.8 & 0.00 & $98 \%$ \\
\hline MSMEG_2713 & peptidase M52, hydrogen uptake protein & & 2.4 & 10.7 & 0.00 & $100 \%$ \\
\hline MSMEG_2714 & hypothetical protein & & 2.1 & 10.6 & 0.00 & $100 \%$ \\
\hline
\end{tabular}


Appendix Table 3. Cont.

\begin{tabular}{|c|c|c|c|c|c|c|}
\hline Primary Target & Common Name & Gene & $\begin{array}{l}\text { Intensity } \\
\text { Ratio }\end{array}$ & $\begin{array}{l}\text { Average Channel } \\
\text { Intensity }\end{array}$ & p-value & $\begin{array}{l}\text { Probability of } \\
\text { Differential } \\
\text { Expression }\end{array}$ \\
\hline MSMEG_2715 & conserved hypothetical protein & & 2.0 & 9.8 & 0.00 & $94 \%$ \\
\hline MSMEG_2716 & conserved hypothetical protein & & 2.1 & 10.2 & 0.00 & $100 \%$ \\
\hline MSMEG_2718 & $\begin{array}{l}\text { iron-sulfur cluster-binding protein, Rieske family } \\
\text { protein, putative }\end{array}$ & & 2.4 & 10.3 & 0.00 & $95 \%$ \\
\hline MSMEG_2719 & hydrogen:quinone oxidoreductase & & 2.7 & 10.8 & 0.00 & $98 \%$ \\
\hline MSMEG_2720 & NADH ubiquinone oxidoreductase, $20 \mathrm{kda}$ subunit & & 2.7 & 11.3 & 0.00 & $99 \%$ \\
\hline \multicolumn{7}{|c|}{ Oxydative Stress } \\
\hline MSMEG_3461 & catalase/peroxidase HPI & katG & 2.7 & 11.1 & 0.00 & $97 \%$ \\
\hline MSMEG_3708 & catalase & & 2.3 & 10.6 & 0.00 & $82 \%$ \\
\hline MSMEG_6213 & Manganese containing catalase & & 2.0 & 10.8 & 0.00 & $99 \%$ \\
\hline \multicolumn{7}{|c|}{ Nitrogen Limitation } \\
\hline MSMEG_0427 & nitrite reductase $[\mathrm{NAD}(\mathrm{P}) \mathrm{H}]$, large subunit & nirB & 2.3 & 11.4 & 0.00 & $100 \%$ \\
\hline MSMEG_0428 & nitrite reductase $[\mathrm{NAD}(\mathrm{P}) \mathrm{H}]$ small subunit & & 2.9 & 11.0 & 0.00 & $100 \%$ \\
\hline MSMEG_0429 & putative ferric uptake regulator & & 1.1 & 9.6 & 0.00 & $77 \%$ \\
\hline MSMEG_0431 & secreted protein & & 1.0 & 10.5 & 0.00 & $67 \%$ \\
\hline MSMEG_0432 & uroporphyrinogen-III synthetase & & 1.6 & 9.4 & 0.00 & $88 \%$ \\
\hline MSMEG_0433 & nitrite extrusion protein & & 1.8 & 12.1 & 0.00 & $97 \%$ \\
\hline MSMEG_0434 & $\begin{array}{l}\text { aminoglycoside 2'-N-acetyltransferase (AAC(2')- } \\
\text { Id) }\end{array}$ & & 1.4 & 10.7 & 0.00 & $84 \%$ \\
\hline MSMEG_0435 & allophanate hydrolase subunit 2 & & 1.8 & 11.8 & 0.00 & $99 \%$ \\
\hline MSMEG_0436 & allophanate hydrolase subunit 1 & & 1.2 & 12.6 & 0.00 & $96 \%$ \\
\hline \multicolumn{7}{|c|}{ Other Stress Related } \\
\hline MSMEG_1597 & Transcription factor WhiB & & 1.5 & 9.9 & 0.00 & $86 \%$ \\
\hline MSMEG_1764 & L-lysine-epsilon aminotransferase & & 2.2 & 11.2 & 0.00 & $99 \%$ \\
\hline MSMEG_1769 & UsfY protein & & 0.8 & 10.7 & 0.00 & $78 \%$ \\
\hline MSMEG_1787 & RsbW protein & & 0.8 & 10.2 & 0.00 & $74 \%$ \\
\hline
\end{tabular}


Appendix Table 3. Cont.

\begin{tabular}{|l|l|l|l|l|l|}
\hline Primary Target & Common Name & Gene & $\begin{array}{l}\text { Intensity } \\
\text { Ratio }\end{array}$ & $\begin{array}{l}\text { Average Channel } \\
\text { Intensity }\end{array}$ & $\begin{array}{l}\text { Probability of } \\
\text { Differential } \\
\text { Expression }\end{array}$ \\
\hline MSMEG_1791 & UsfY protein & 1.5 & 11.1 & 0.00 & $99 \%$ \\
\hline MSMEG_6467 & starvation-induced DNA protecting protein & 1.5 & 12.8 & 0.06 & $2 \%$ \\
\hline MSMEG_1953 & transcription factor WhiB & 1.0 & 11.6 & 0.00 & $62 \%$ \\
\hline
\end{tabular}

Appendix Table 4. Differential gene expression of sigma factors (non-spray dried log versus stationary comparison).

\begin{tabular}{|l|l|l|l|l|l|}
\hline Primary Target & Common Name & \multicolumn{2}{l|}{$\begin{array}{l}\text { Intensity } \\
\text { Ratio }\end{array}$} & $\begin{array}{l}\text { Average } \\
\text { Channel } \\
\text { Intensity }\end{array}$ & $\begin{array}{l}\text { Probability of } \\
\text { Differential } \\
\text { Expression }\end{array}$ \\
\hline Stationary Phase (Positive Intensity Ratio) & \multicolumn{5}{l|}{} \\
\hline MSMEG_1970 & sigma factor & 4.2 & 11.6 & 0.00 & $99 \%$ \\
\hline MSMEG_1599 & RNA polymerase sigma-70 factor & 1.9 & 10.9 & 0.00 & $98 \%$ \\
\hline MSMEG_6817 & RNA polymerase sigma factor, sigma-70 family protein & 1.3 & 9.7 & 0.00 & $90 \%$ \\
\hline MSMEG_3008 & putative sigma 54 type regulator & 1.1 & 9.6 & 0.00 & $75 \%$ \\
\hline MSMEG_1418 & RNA polymerase ECF-type sigma factor & 0.8 & 10.7 & 0.00 & $64 \%$ \\
\hline MSMEG_0219 & RNA polymerase sigma-70 factor, family protein & 0.8 & 10.4 & 0.02 & $9 \%$ \\
\hline MSMEG_1690 & putative ECF sigma factor RpoE1 & 0.5 & 9.2 & 0.03 & $15 \%$ \\
\hline MSMEG_1666 & RNA polymerase sigma-70 factor & 0.5 & 9.3 & 0.03 & $9 \%$ \\
\hline MSMEG_1486 & RNA polymerase sigma-70 factor & 0.4 & 9.7 & 0.06 & $2 \%$ \\
\hline MSMEG_5444 & RNA polymerase sigma-70 factor & 0.4 & 9.7 & 0.05 & $2 \%$ \\
\hline MSMEG_1914 & RNA polymerase sigma-70 factor, family protein & 0.4 & 11.3 & 0.10 & $1 \%$ \\
\hline MSMEG_5214 & RNA polymerase sigma-70 factor & 0.2 & 9.5 & 0.34 & $0 \%$ \\
\hline MSMEG_5072 & extracytoplasmic function alternative sigma factor & 0.2 & 11.9 & 0.33 & $0 \%$ \\
\hline MSMEG_3296 & ECF-family protein sigma factor H & 0.2 & 9.2 & 0.26 & $0 \%$ \\
\hline MSMEG_1692 & ECF-family protein RNA polymerase sigma factor & 0.1 & 9.3 & 0.47 & $0 \%$ \\
\hline MSMEG_4315 & RNA polymerase sigma factor, sigma-70 family protein & 0.1 & 10.4 & 0.66 & $0 \%$ \\
\hline
\end{tabular}


Appendix Table 4. Cont.

\begin{tabular}{|c|c|c|c|c|c|}
\hline Primary Target & Common Name & $\begin{array}{l}\text { Intensity } \\
\text { Ratio }\end{array}$ & $\begin{array}{l}\text { Average } \\
\text { Channel } \\
\text { Intensity }\end{array}$ & p-value & $\begin{array}{l}\text { Probability of } \\
\text { Differential } \\
\text { Expression }\end{array}$ \\
\hline MSMEG_0574 & putative ECF sigma factor RpoE1 & 0.0 & 9.3 & 0.57 & $0 \%$ \\
\hline MSMEG_5365 & RNA polymerase sigma- 70 factor & -0.8 & 10.1 & 0.00 & $59 \%$ \\
\hline MSMEG 0405 & extra cytoplasmic sigma factor & -0.6 & 10.1 & 0.01 & $38 \%$ \\
\hline MSMEG_1804 & RNA polymerase sigma-F factor & -0.3 & 11.2 & 0.09 & $1 \%$ \\
\hline MSMEG_3485 & putative ECF sigma factor RpoE1 & -0.3 & 9.6 & 0.21 & $0 \%$ \\
\hline MSMEG 2758 & sigma factor MysA & -0.2 & 12.0 & 0.19 & $0 \%$ \\
\hline MSMEG_6931 & RNA polymerase sigma- 70 factor & -0.2 & 9.5 & 0.37 & $0 \%$ \\
\hline MSMEG_0573 & putative ECF sigma factor RpoE1 & -0.2 & 10.8 & 0.44 & $0 \%$ \\
\hline MSMEG_2752 & sigma factor SigB & -0.2 & 12.8 & 0.39 & $0 \%$ \\
\hline MSMEG_4405 & putative ECF sigma factor RpoE1 & -0.1 & 9.3 & 0.60 & $0 \%$ \\
\hline
\end{tabular}

Appendix Table 5. Log phase differential gene expression in multiply cycled bacteria versus non-previously spray dried bacteria (positive expression indicates stationary phase).

\begin{tabular}{|c|c|c|c|c|c|c|}
\hline Primary Target & Common Name & Gene & $\begin{array}{l}\text { Intensity } \\
\text { Ratio }\end{array}$ & $\begin{array}{l}\text { Average Channel } \\
\text { Intensity }\end{array}$ & p-value & $\begin{array}{l}\text { Probability of } \\
\text { Differential } \\
\text { Expression }\end{array}$ \\
\hline MSMEG_0267 & esterase & & 0.6 & 9.1 & 0.047 & $53 \%$ \\
\hline MSMEG_0451 & oxidoreductase, FAD-linked & & 0.7 & 10.9 & 0.017 & $84 \%$ \\
\hline MSMEG_0536 & intracellular protease, $\mathrm{PfpI}$ family protein & & 0.8 & 10.4 & 0.008 & $93 \%$ \\
\hline MSMEG_0670 & FAD dependent oxidoreductase & & 0.5 & 9.4 & 0.043 & $57 \%$ \\
\hline
\end{tabular}


Appendix Table 5. Cont.

\begin{tabular}{|c|c|c|c|c|c|c|}
\hline Primary Target & Common Name & Gene & $\begin{array}{l}\text { Intensity } \\
\text { Ratio }\end{array}$ & $\begin{array}{l}\text { Average Channel } \\
\text { Intensity }\end{array}$ & p-value & $\begin{array}{l}\text { Probability of } \\
\text { Differential } \\
\text { Expression }\end{array}$ \\
\hline MSMEG_0671 & S-(hydroxymethyl)glutathione dehydrogenase & & 0.7 & 10.1 & 0.014 & $91 \%$ \\
\hline MSMEG_0672 & conserved hypothetical protein & & 1.4 & 12.6 & 0.027 & $68 \%$ \\
\hline MSMEG_0685 & oxidoreductase, molybdopterin-binding subunit & & 0.7 & 10.0 & 0.020 & $89 \%$ \\
\hline MSMEG_1076 & conserved hypothetical protein & & 2.0 & 12.3 & 0.002 & $100 \%$ \\
\hline MSMEG_1097 & glycosyl transferase, group 2 family protein & & 1.5 & 11.6 & 0.002 & $100 \%$ \\
\hline MSMEG_1131 & tryptophan-rich sensory protein & & 1.1 & 10.6 & 0.032 & $70 \%$ \\
\hline MSMEG_1558 & conserved hypothetical protein & & 0.8 & 9.5 & 0.032 & $73 \%$ \\
\hline MSMEG_1605 & phosphate transport system regulatory protein $\mathrm{PhoU}$ & phoU & 0.6 & 9.3 & 0.009 & $91 \%$ \\
\hline MSMEG_1766 & conserved hypothetical protein & & 0.8 & 9.1 & 0.026 & $78 \%$ \\
\hline MSMEG_1767 & conserved hypothetical protein & & 0.9 & 10.1 & 0.004 & $98 \%$ \\
\hline MSMEG_1768 & conserved hypothetical protein & & 0.9 & 9.2 & 0.012 & $96 \%$ \\
\hline MSMEG_1769 & UsfY protein & & 1.3 & 9.6 & 0.002 & $100 \%$ \\
\hline MSMEG_1770 & conserved hypothetical protein & & 1.7 & 10.7 & 0.001 & $100 \%$ \\
\hline MSMEG_1771 & methylase, putative & & 1.3 & 10.9 & 0.006 & $95 \%$ \\
\hline MSMEG_1772 & conserved hypothetical protein & & 1.5 & 9.9 & 0.005 & $99 \%$ \\
\hline MSMEG_1773 & conserved hypothetical protein & & 1.1 & 10.7 & 0.007 & $95 \%$ \\
\hline MSMEG_1774 & conserved hypothetical protein & & 1.2 & 11.5 & 0.020 & $76 \%$ \\
\hline MSMEG_1777 & UsfY protein & & 1.3 & 11.5 & 0.005 & $97 \%$ \\
\hline MSMEG_1782 & $\begin{array}{l}\text { oxidoreductase, short chain } \\
\text { dehydrogenase/reductase family protein }\end{array}$ & & 0.7 & 10.6 & 0.021 & $87 \%$ \\
\hline MSMEG_1783 & hypothetical protein & & 0.6 & 9.6 & 0.042 & $78 \%$ \\
\hline MSMEG_1788 & conserved hypothetical protein & & 1.4 & 10.7 & 0.003 & $98 \%$ \\
\hline MSMEG_1789 & conserved hypothetical protein & & 1.4 & 10.8 & 0.007 & $93 \%$ \\
\hline MSMEG_1790 & conserved hypothetical protein & & 1.2 & 9.5 & 0.005 & $98 \%$ \\
\hline MSMEG_1792 & conserved hypothetical protein & & 0.5 & 9.5 & 0.046 & $55 \%$ \\
\hline
\end{tabular}


Appendix Table 5. Cont.

\begin{tabular}{|c|c|c|c|c|c|c|}
\hline Primary Target & Common Name & Gene & $\begin{array}{l}\text { Intensity } \\
\text { Ratio }\end{array}$ & $\begin{array}{l}\text { Average Channel } \\
\text { Intensity }\end{array}$ & p-value & $\begin{array}{l}\text { Probability of } \\
\text { Differential } \\
\text { Expression }\end{array}$ \\
\hline MSMEG_1794 & dehydrogenase & & 0.6 & 9.4 & 0.020 & $81 \%$ \\
\hline MSMEG_1802 & ChaB protein & & 0.8 & 9.2 & 0.033 & $89 \%$ \\
\hline MSMEG_1821 & acyl-CoA dehydrogenase & & -0.6 & 9.4 & 0.017 & $79 \%$ \\
\hline MSMEG_1886 & Fatty acid desaturase & & 0.9 & 9.9 & 0.012 & $88 \%$ \\
\hline MSMEG_1950 & conserved hypothetical protein & & 1.0 & 10.2 & 0.004 & $98 \%$ \\
\hline MSMEG_1951 & conserved domain protein & & 1.7 & 10.5 & 0.003 & $99 \%$ \\
\hline MSMEG_1952 & ATP-dependent DNA helicase & & 0.6 & 9.7 & 0.029 & $76 \%$ \\
\hline MSMEG_2112 & secreted protein & & 1.0 & 10.1 & 0.006 & $96 \%$ \\
\hline MSMEG_2115 & conserved hypothetical protein & & 1.0 & 9.7 & 0.004 & $99 \%$ \\
\hline MSMEG_2345 & lycopene cyclase & & 0.7 & 8.7 & 0.042 & $75 \%$ \\
\hline MSMEG_2346 & phytoene synthase & & 1.0 & 9.0 & 0.003 & $99 \%$ \\
\hline MSMEG_2376 & conserved hypothetical protein & & 0.7 & 9.1 & 0.018 & $79 \%$ \\
\hline MSMEG_2415 & hemerythrin HHE cation binding region & & 1.1 & 10.3 & 0.003 & $99 \%$ \\
\hline MSMEG_2593 & gnat-family protein acetyltransferase & & 0.9 & 10.1 & 0.005 & $98 \%$ \\
\hline MSMEG 2594 & asparagine synthase (glutamine-hydrolyzing) & asnB & 0.8 & 9.9 & 0.010 & $92 \%$ \\
\hline MSMEG_2913 & hydrolase & & 0.6 & 9.2 & 0.021 & $76 \%$ \\
\hline MSMEG 2924 & permease binding-protein component & & 0.7 & 10.2 & 0.021 & $90 \%$ \\
\hline MSMEG_2925 & permease membrane component & & 0.9 & 8.9 & 0.008 & $92 \%$ \\
\hline MSMEG_2926 & $\begin{array}{l}\text { glycine betaine/carnitine/choline transport ATP- } \\
\text { binding protein opuCA }\end{array}$ & & 1.0 & 10.1 & 0.006 & $98 \%$ \\
\hline MSMEG_2958 & conserved hypothetical protein & & 1.0 & 10.3 & 0.003 & $98 \%$ \\
\hline MSMEG_3022 & transglycosylase associated protein & & 1.6 & 10.5 & 0.008 & $94 \%$ \\
\hline MSMEG_3184 & malto-oligosyltrehalose trehalohydrolase & treZ & 0.8 & 9.4 & 0.012 & $90 \%$ \\
\hline MSMEG 3185 & putative maltooligosyl trehalose synthase & & 0.8 & 10.2 & 0.006 & $95 \%$ \\
\hline MSMEG_3186 & glycogen debranching enzyme GlgX & $\operatorname{glg} X$ & 0.6 & 10.8 & 0.041 & $77 \%$ \\
\hline
\end{tabular}


Appendix Table 5. Cont.

\begin{tabular}{|c|c|c|c|c|c|c|}
\hline Primary Target & Common Name & Gene & $\begin{array}{l}\text { Intensity } \\
\text { Ratio }\end{array}$ & $\begin{array}{l}\text { Average Channel } \\
\text { Intensity }\end{array}$ & p-value & $\begin{array}{l}\text { Probability of } \\
\text { Differential } \\
\text { Expression } \\
\end{array}$ \\
\hline MSMEG_3254 & RDD family protein, putative & & 1.0 & 10.6 & 0.004 & $98 \%$ \\
\hline MSMEG_3255 & DoxX subfamily protein, putative & & 1.3 & 10.1 & 0.002 & $100 \%$ \\
\hline MSMEG_3418 & conserved hypothetical protein & & 0.8 & 9.7 & 0.009 & $95 \%$ \\
\hline MSMEG_3419 & hypothetical protein & & 1.2 & 10.3 & 0.006 & $96 \%$ \\
\hline MSMEG_3543 & soluble secreted antigen MPT53 & & 0.8 & 9.5 & 0.044 & $94 \%$ \\
\hline MSMEG_4325 & malonyl CoA-acyl carrier protein transacylase & & -0.9 & 12.1 & 0.020 & $88 \%$ \\
\hline MSMEG_4918 & 1,4-alpha-glucan branching enzyme & $\operatorname{glgB}$ & 0.7 & 10.3 & 0.022 & $75 \%$ \\
\hline MSMEG_4991 & hypothetical protein & & 0.7 & 9.8 & 0.017 & $83 \%$ \\
\hline MSMEG_4993 & hypothetical protein & & 1.0 & 10.3 & 0.007 & $93 \%$ \\
\hline MSMEG_5342 & conserved hypothetical protein & & 0.9 & 9.1 & 0.018 & $89 \%$ \\
\hline MSMEG_5343 & conserved hypothetical protein & & 1.1 & 9.2 & 0.010 & $98 \%$ \\
\hline MSMEG_5542 & transcriptional regulator, HTH_3 family protein & & 1.0 & 9.4 & 0.008 & $93 \%$ \\
\hline MSMEG_5543 & hypothetical protein & & 1.8 & 10.4 & 0.002 & $99 \%$ \\
\hline MSMEG_5616 & $\begin{array}{l}\text { glyoxalase/bleomycin resistance } \\
\text { protein/dioxygenase }\end{array}$ & & 0.7 & 8.7 & 0.017 & $89 \%$ \\
\hline MSMEG_5617 & immunogenic protein MPT63 & & 1.6 & 10.6 & 0.004 & $99 \%$ \\
\hline MSMEG_5722 & conserved hypothetical protein & & 0.6 & 9.5 & 0.038 & $71 \%$ \\
\hline MSMEG_5936 & conserved hypothetical protein & & 1.1 & 10.9 & 0.003 & $98 \%$ \\
\hline MSMEG_6211 & hypothetical protein & & 0.8 & 10.5 & 0.011 & $93 \%$ \\
\hline MSMEG_6212 & $\begin{array}{l}\text { hemerythrin HHE cation binding domain subfamily } \\
\text { protein, putative }\end{array}$ & & 1.0 & 10.9 & 0.025 & $98 \%$ \\
\hline MSMEG_6213 & Manganese containing catalase & & 1.0 & 9.1 & 0.011 & $94 \%$ \\
\hline MSMEG_6232 & catalase KatA & katA & 0.7 & 8.8 & 0.030 & $73 \%$ \\
\hline MSMEG_6305 & conserved hypothetical protein & & 0.6 & 9.1 & 0.027 & $74 \%$ \\
\hline MSMEG_6355 & hypothetical protein & & 0.7 & 9.1 & 0.024 & $78 \%$ \\
\hline MSMEG_6467 & starvation-induced DNA protecting protein & & 1.6 & 10.5 & 0.002 & $99 \%$ \\
\hline
\end{tabular}


Appendix Table 5. Cont.

\begin{tabular}{|l|l|l|l|l|l|l|}
\hline Primary Target & Common Name & Gene & $\begin{array}{l}\text { Intensity } \\
\text { Ratio }\end{array}$ & $\begin{array}{l}\text { Average Channel } \\
\text { Intensity }\end{array}$ & $\begin{array}{l}\text { Probability of } \\
\text { Differential } \\
\text { Expression }\end{array}$ \\
\hline MSMEG_6507 & glycogen debranching enzyme GlgX & glgX & 0.9 & 10.2 & 0.013 & $97 \%$ \\
\hline MSMEG_6579 & conserved hypothetical protein & & 0.6 & 10.6 & 0.026 & $69 \%$ \\
\hline MSMEG_6616 & S-(hydroxymethyl)glutathione dehydrogenase & & 0.7 & 9.9 & 0.014 & $87 \%$ \\
\hline
\end{tabular}

Appendix Table 6. Stationary phase differential gene expression in multiply cycled bacteria versus non-previously spray dried bacteria (positive expression indicates stationary phase).

\begin{tabular}{|c|c|c|c|c|c|}
\hline Primary Target & Common Name & Gene & $\begin{array}{l}\text { Intensity } \\
\text { Ratio }\end{array}$ & $\begin{array}{l}\text { Average } \\
\text { Channel } \\
\text { Intensity }\end{array}$ & $\begin{array}{l}\text { Probability of } \\
\text { Differential } \\
\text { Expression }\end{array}$ \\
\hline MSMEG_0536 & intracellular protease, PfpI family protein & & 0.9 & 11.6 & $60 \%$ \\
\hline MSMEG_0641 & $\begin{array}{l}\text { binding-protein-dependent transport systems inner membrane } \\
\text { component }\end{array}$ & & -0.6 & 10.4 & $21 \%$ \\
\hline MSMEG_0671 & S-(hydroxymethyl)glutathione dehydrogenase & & 1.1 & 10.9 & $27 \%$ \\
\hline MSMEG_0696 & alanine-rich protein & & 0.6 & 9.8 & $21 \%$ \\
\hline MSMEG_1112 & aconitate hydratase, putative & & 1.0 & 10.2 & $25 \%$ \\
\hline MSMEG_1679 & AmiB & & -0.9 & 10.8 & $30 \%$ \\
\hline MSMEG_1683 & $\begin{array}{l}\text { cytosine/purine/uracil/thiamine/allantoin permease family } \\
\text { protein }\end{array}$ & & -0.7 & 12.0 & $39 \%$ \\
\hline MSMEG_1767 & conserved hypothetical protein & & 1.3 & 10.8 & $49 \%$ \\
\hline MSMEG_1768 & conserved hypothetical protein & & 0.8 & 9.7 & $37 \%$ \\
\hline MSMEG_1769 & UsfY protein & & 1.0 & 10.0 & $56 \%$ \\
\hline MSMEG_1772 & conserved hypothetical protein & & 1.1 & 10.3 & $40 \%$ \\
\hline MSMEG_1790 & conserved hypothetical protein & & 1.4 & 10.4 & $62 \%$ \\
\hline MSMEG_1950 & conserved hypothetical protein & & 1.1 & 10.7 & $33 \%$ \\
\hline MSMEG_1951 & conserved domain protein & & 2.3 & 11.5 & $34 \%$ \\
\hline
\end{tabular}


Appendix Table 6. Cont.

\begin{tabular}{|c|c|c|c|c|c|}
\hline Primary Target & Common Name & Gene & $\begin{array}{l}\text { Intensity } \\
\text { Ratio }\end{array}$ & $\begin{array}{l}\text { Average } \\
\text { Channel } \\
\text { Intensity }\end{array}$ & $\begin{array}{l}\text { Probability of } \\
\text { Differential } \\
\text { Expression } \\
\end{array}$ \\
\hline MSMEG_2115 & conserved hypothetical protein & & 2.1 & 11.2 & $61 \%$ \\
\hline MSMEG_2346 & phytoene synthase & & 1.5 & 10.3 & $66 \%$ \\
\hline MSMEG_2347 & phytoene dehydrogenase & & 0.8 & 11.0 & $21 \%$ \\
\hline MSMEG_2389 & DNA-binding protein $\mathrm{HU}$ & hup & -0.9 & 11.4 & $22 \%$ \\
\hline MSMEG_2752 & sigma factor SigB & & 1.2 & 11.2 & $37 \%$ \\
\hline MSMEG_2958 & conserved hypothetical protein & & 1.2 & 11.9 & $28 \%$ \\
\hline MSMEG_3185 & putative maltooligosyl trehalose synthase & & 0.7 & 10.9 & $28 \%$ \\
\hline MSMEG_3254 & RDD family protein, putative & & 1.7 & 11.9 & $28 \%$ \\
\hline MSMEG_3439 & hypothetical protein & & 2.4 & 12.2 & $25 \%$ \\
\hline MSMEG_4208 & integral membrane protein & & -0.9 & 10.8 & $60 \%$ \\
\hline MSMEG_5152 & hypothetical protein & & -0.8 & 11.9 & $27 \%$ \\
\hline MSMEG_5542 & transcriptional regulator, HTH_3 family protein & & 1.4 & 10.1 & $55 \%$ \\
\hline MSMEG_6213 & Manganese containing catalase & & 1.0 & 10.3 & $55 \%$ \\
\hline MSMEG_6242 & alcohol dehydrogenase, iron-containing & & -1.3 & 12.4 & $51 \%$ \\
\hline MSMEG_6579 & conserved hypothetical protein & & 1.1 & 11.5 & $21 \%$ \\
\hline MSMEG_6759 & glycerol kinase & glpK & -1.2 & 12.4 & $61 \%$ \\
\hline MSMEG_6761 & glycerol-3-phosphate dehydrogenase 2 & & -1.7 & 12.9 & $33 \%$ \\
\hline
\end{tabular}

Appendix Table 7. Differential gene expression in non-previously spray dried bacteria in dry powder state.

\begin{tabular}{|c|c|c|c|c|c|c|}
\hline Primary Target & Common Name & Gene & $\begin{array}{l}\text { Intensity } \\
\text { Ratio }\end{array}$ & $\begin{array}{l}\text { Average } \\
\text { Channel } \\
\text { Intensity }\end{array}$ & p-value & $\begin{array}{l}\text { Probability of } \\
\text { Differential } \\
\text { Expression }\end{array}$ \\
\hline MSMEG_0114 & extracellular solute-binding protein, family protein 3 & & 1.6 & 8.7 & 0.008 & $95 \%$ \\
\hline MSMEG_0373 & 3-ketoacyl-CoA thiolase & & 1.3 & 12.4 & 0.008 & $89 \%$ \\
\hline MSMEG_0614 & methyltransferase & & 1.4 & 9.9 & 0.010 & $74 \%$ \\
\hline
\end{tabular}


Appendix Table 7. Cont.

\begin{tabular}{|c|c|c|c|c|c|c|}
\hline Primary Target & Common Name & Gene & $\begin{array}{l}\text { Intensity } \\
\text { Ratio }\end{array}$ & $\begin{array}{l}\text { Average } \\
\text { Channel } \\
\text { Intensity }\end{array}$ & p-value & $\begin{array}{l}\text { Probability of } \\
\text { Differential } \\
\text { Expression }\end{array}$ \\
\hline MSMEG 1130 & hypothetical protein & & 2.1 & 7.8 & 0.009 & $77 \%$ \\
\hline MSMEG_1452 & sulfatase-modifying factor 1 & & 2.8 & 8.3 & 0.008 & $90 \%$ \\
\hline MSMEG 1479 & methyltransferase, putative, family protein & & 1.1 & 9.8 & 0.010 & $73 \%$ \\
\hline MSMEG 1482 & methyltransferase & & 1.4 & 10.9 & 0.010 & $68 \%$ \\
\hline MSMEG_1530 & integral membrane protein & & 1.8 & 10.2 & 0.008 & $92 \%$ \\
\hline MSMEG_1843 & adenosylhomocysteinase & ahcY & 1.2 & 10.3 & 0.009 & $82 \%$ \\
\hline MSMEG_1887 & hypothetical protein & & 1.3 & 12.2 & 0.010 & $71 \%$ \\
\hline MSMEG 1888 & methyltransferase & & 1.6 & 8.4 & 0.008 & $92 \%$ \\
\hline MSMEG 1911 & catechol 1,2-dioxygenase & catA & 1.4 & 10.4 & 0.009 & $83 \%$ \\
\hline MSMEG 1960 & hypothetical protein & & 2.0 & 8.2 & 0.010 & $73 \%$ \\
\hline MSMEG 2081 & putative acyl-CoA dehydrogenase & & 1.4 & 12.6 & 0.009 & $81 \%$ \\
\hline MSMEG_2316 & monooxygenase, NtaA/SnaA/SoxA family & & 1.2 & 10.3 & 0.009 & $82 \%$ \\
\hline MSMEG_2507 & IclR-family protein transcriptional regulator & & 2.0 & 8.0 & 0.010 & $74 \%$ \\
\hline MSMEG_2511 & siderophore utilization protein & & 1.1 & 10.7 & 0.009 & $74 \%$ \\
\hline MSMEG_2748 & soluble pyridine nucleotide transhydrogenase & sthA & 4.1 & 8.5 & 0.008 & $96 \%$ \\
\hline MSMEG_2799 & phospho-2-dehydro-3-deoxyheptonate aldolase & & 1.4 & 9.6 & 0.009 & $85 \%$ \\
\hline MSMEG_3215 & $\begin{array}{l}\text { ABC-type molybdenum transport system, ATPase } \\
\text { component/photorepair protein PhrA }\end{array}$ & & 1.3 & 10.4 & 0.008 & $84 \%$ \\
\hline MSMEG_3233 & cytochrome D ubiquinol oxidase subunit 1 & & 1.3 & 10.6 & 0.009 & $78 \%$ \\
\hline MSMEG_3724 & coenzyme PQQ biosynthesis protein B & pqqB & 2.1 & 7.6 & 0.009 & $76 \%$ \\
\hline MSMEG_3902 & ATPase,AAA family protein & & 1.4 & 12.2 & 0.010 & $74 \%$ \\
\hline MSMEG_4085 & nitrilotriacetate monooxygenase component $\mathrm{A}$ & & 1.2 & 8.8 & 0.009 & $80 \%$ \\
\hline MSMEG_4107 & Phosphoglycerate mutase, putative & & 2.1 & 7.9 & 0.009 & $77 \%$ \\
\hline MSMEG_4372 & capreomycidine hydroxylase & & 2.3 & 7.0 & 0.008 & $84 \%$ \\
\hline MSMEG_4576 & SpfH domain protein & & 1.1 & 8.0 & 0.009 & $73 \%$ \\
\hline
\end{tabular}


Appendix Table 7. Cont.

\begin{tabular}{|c|c|c|c|c|c|c|}
\hline Primary Target & Common Name & Gene & $\begin{array}{l}\text { Intensity } \\
\text { Ratio }\end{array}$ & $\begin{array}{l}\text { Average } \\
\text { Channel } \\
\text { Intensity }\end{array}$ & p-value & $\begin{array}{l}\text { Probability of } \\
\text { Differential } \\
\text { Expression }\end{array}$ \\
\hline MSMEG_5005 & LprC protein & & 1.1 & 8.9 & 0.010 & $72 \%$ \\
\hline MSMEG_5216 & glyoxalase family protein & & 1.7 & 8.3 & 0.008 & $89 \%$ \\
\hline MSMEG_5226 & exodeoxyribonuclease VII, large subunit & $\mathrm{xseA}$ & 1.1 & 9.0 & 0.009 & $76 \%$ \\
\hline MSMEG_5364 & amidohydrolase 2 & & 1.2 & 10.7 & 0.010 & $71 \%$ \\
\hline MSMEG_5486 & peptidase S1 and S6, chymotrypsin/Hap & & 1.7 & 13.1 & 0.008 & $95 \%$ \\
\hline MSMEG_5646 & conserved hypothetical protein & & 2.0 & 11.1 & 0.008 & $92 \%$ \\
\hline MSMEG_5745 & gas vesicle synthesis protein & & 2.0 & 8.3 & 0.010 & $73 \%$ \\
\hline MSMEG_5789 & putative thiosulfate sulfurtransferase & & 1.2 & 11.2 & 0.009 & $78 \%$ \\
\hline MSMEG_5861 & cytochrome P450 109 & & 2.0 & 8.2 & 0.009 & $76 \%$ \\
\hline MSMEG_5887 & intersectin-EH binding protein Ibp1 & & 1.2 & 11.8 & 0.010 & $70 \%$ \\
\hline MSMEG_5912 & succinic semialdehyde dehydrogenase & & 1.4 & 9.6 & 0.008 & $92 \%$ \\
\hline MSMEG_5982 & UDP-glucose 6-dehydrogenase & & 2.9 & 7.7 & 0.008 & $91 \%$ \\
\hline MSMEG_6254 & hypothetical protein & & 1.5 & 10.1 & 0.009 & $88 \%$ \\
\hline MSMEG_6332 & amino acid $\mathrm{ABC}$ transporter, permease protein & & 2.0 & 7.6 & 0.010 & $73 \%$ \\
\hline MSMEG_6454 & conserved hypothetical protein & & 1.6 & 11.9 & 0.008 & $92 \%$ \\
\hline MSMEG_6512 & acyl-CoA dehydrogenase domain protein & & 1.5 & 11.4 & 0.008 & $86 \%$ \\
\hline
\end{tabular}

Appendix Table 8. Differential gene expression in multiply cycled bacteria in dry powder state.

\begin{tabular}{|c|c|c|c|c|c|c|}
\hline Primary Target & Common Name & Gene & $\begin{array}{l}\text { Intensity } \\
\text { Ratio }\end{array}$ & $\begin{array}{l}\text { Average Channel } \\
\text { Intensity }\end{array}$ & p-value & \begin{tabular}{|l} 
Probability of \\
Differential \\
Expression
\end{tabular} \\
\hline \multicolumn{7}{|l|}{ Lipid Synthesis } \\
\hline MSMEG_2337 & isopentenyl-diphosphate delta-isomerase, type 2 & fni & 1.23 & 12.2 & 0.010 & $65 \%$ \\
\hline MSMEG_4326 & acyl carrier protein & acpP & 1.58 & 10.5 & 0.008 & $89 \%$ \\
\hline MSMEG_4327 & 3-oxoacyl-[acyl-carrier-protein] synthase 1 & & 1.37 & 10.6 & 0.010 & $67 \%$ \\
\hline
\end{tabular}


Appendix Table 8. Cont.

\begin{tabular}{|c|c|c|c|c|c|c|}
\hline Primary Target & Common Name & Gene & $\begin{array}{l}\text { Intensity } \\
\text { Ratio }\end{array}$ & $\begin{array}{l}\text { Average Channel } \\
\text { Intensity }\end{array}$ & p-value & $\begin{array}{l}\text { Probability } \\
\text { of } \\
\text { Differential } \\
\text { Expression }\end{array}$ \\
\hline MSMEG_4328 & 3-oxoacyl-[acyl-carrier-protein] synthase 2 & & 1.79 & 10.5 & 0.009 & $87 \%$ \\
\hline MSMEG_4329 & propionyl-CoA carboxylase beta chain & & 1.78 & 10.6 & 0.008 & $91 \%$ \\
\hline MSMEG_5242 & acyltransferase, ws/dgat/mgat subfamily protein & & 1.68 & 10.4 & 0.009 & $83 \%$ \\
\hline \multicolumn{7}{|l|}{ Transposases } \\
\hline MSMEG_1862 & transposase & & 1.04 & 10.2 & 0.012 & $49 \%$ \\
\hline MSMEG 2824 & IS1549, transposase & & 1.24 & 10.5 & 0.019 & $27 \%$ \\
\hline MSMEG_4522 & ISMsm2, transposase & & 1.37 & 11.1 & 0.008 & $91 \%$ \\
\hline MSMEG 4072 & ISMsm5, transposase & & 1.40 & 10.1 & 0.009 & $84 \%$ \\
\hline MSMEG_2805 & ISMsm5, transposase & & 1.43 & 11.4 & 0.008 & $88 \%$ \\
\hline MSMEG_2830 & ISMsm4, transposase & & 1.44 & 10.8 & 0.009 & $84 \%$ \\
\hline MSMEG_4791 & IS1096, tnpR protein & & 1.61 & 11.3 & 0.010 & $70 \%$ \\
\hline MSMEG_3341 & Transposase IS116/IS110/IS902 family protein & & 1.62 & 10.3 & 0.008 & $95 \%$ \\
\hline MSMEG_3984 & Transposase IS116/IS110/IS902 family protein & & 1.99 & 11.0 & 0.010 & $82 \%$ \\
\hline MSMEG_1731 & IS6120, transposase & & 2.05 & 10.4 & 0.008 & $94 \%$ \\
\hline MSMEG_4926 & IS1096, tnpA protein & & 2.24 & 12.3 & 0.008 & $98 \%$ \\
\hline \multicolumn{7}{|c|}{ IS1096 Related } \\
\hline MSMEG_6696 & hypothetical protein & & 1.91 & 11.2 & 0.008 & $98 \%$ \\
\hline MSMEG_0803 & hypothetical protein & & 1.90 & 12.8 & 0.008 & $98 \%$ \\
\hline MSMEG_0396 & hypothetical protein & & 1.87 & 12.1 & 0.008 & $96 \%$ \\
\hline MSMEG_1259 & hypothetical protein & & 1.16 & 10.8 & 0.011 & $67 \%$ \\
\hline \multicolumn{7}{|l|}{ Other } \\
\hline MSMEG_0051 & transcription factor WhiB family protein & & 1.70 & 10.3 & 0.008 & $93 \%$ \\
\hline MSMEG_1599 & RNA polymerase sigma- 70 factor & & 1.12 & 10.9 & 0.009 & $73 \%$ \\
\hline MSMEG_2294 & DNA polymerase IV & $\operatorname{din} B$ & 1.72 & 10.3 & 0.009 & $90 \%$ \\
\hline
\end{tabular}


Appendix Table 9. Probability of expression of the carotenoid biosynthesis operon across the different experiments.

\begin{tabular}{|l|l|l|l|l|l|l|}
\hline & & \multicolumn{2}{|l|}{$\begin{array}{l}\text { Naïve Stationary vs. } \\
\text { Naïve Log }\end{array}$} & $\begin{array}{l}\text { Cycled Log } \\
\text { vs. Naive Log }\end{array}$ & $\begin{array}{l}\text { Cycled Stationary } \\
\text { vs. Naive Stationary }\end{array}$ & $\begin{array}{l}\text { Cycled Powder } \\
\text { vs. Naive Powder }\end{array}$ \\
\hline Primary Target & Common Name of Primary Target & Probability of Differential Expression & & $\sigma$ above median \\
\hline MSMEG_2343 & methylesterase & $1 \%$ & $8 \%$ & $19 \%$ & $0 \%$ & 2.5 \\
\hline MSMEG_2344 & dehydrogenase & $1 \%$ & $35 \%$ & $14 \%$ & $1 \%$ & $10 \%$ \\
\hline MSMEG_2345 & lycopene cyclase & $0 \%$ & $75 \%$ & $17 \%$ & 2.7 \\
\hline MSMEG_2346 & phytoene synthase & $5 \%$ & $99 \%$ & $66 \%$ & $0 \%$ \\
\hline MSMEG_2347 & phytoene dehydrogenase & $0 \%$ & $55 \%$ & $21 \%$ & 2.3 & $1 \%$ \\
\hline
\end{tabular}

Appendix Table 10. Results of sigF consensus promoter analysis.

\begin{tabular}{|c|c|c|c|c|c|c|c|c|c|c|c|c|c|c|c|}
\hline \multirow[b]{2}{*}{$\begin{array}{l}\text { Primary } \\
\text { Target }\end{array}$} & \multirow[b]{2}{*}{$\begin{array}{l}\text { Common Name } \\
\text { of Primary } \\
\text { Target }\end{array}$} & \multirow[b]{2}{*}{ Promoter Sequence } & \multirow[b]{2}{*}{ BP } & \multicolumn{3}{|c|}{$\begin{array}{l}\text { Naïve Stationary } \\
\text { vs. Naïve Log }\end{array}$} & \multicolumn{3}{|c|}{$\begin{array}{l}\text { Cycled Log } \\
\text { vs. Naive Log }\end{array}$} & \multicolumn{3}{|c|}{$\begin{array}{l}\text { Cycled Stationary } \\
\text { vs. Naive } \\
\text { Stationary } \\
\end{array}$} & \multicolumn{3}{|c|}{$\begin{array}{l}\text { Cycled Powder } \\
\text { vs. Naive } \\
\text { Powder } \\
\end{array}$} \\
\hline & & & & $\mathrm{FC}$ & $\sigma$ & $\mathrm{P}$ & $\mathrm{FC}$ & $\sigma$ & $\mathrm{P}$ & $\mathrm{FC}$ & $\sigma$ & $\mathrm{P}$ & $\mathrm{FC}$ & $\sigma$ & $\mathrm{P}$ \\
\hline & & $-10^{-35}$ & & & & & & & & & & & & & \\
\hline $\begin{array}{l}\text { MSMEG } \\
-1804\end{array}$ & $\begin{array}{l}\text { RNA } \\
\text { polymerase } \\
\text { sigma-F factor }\end{array}$ & $\begin{array}{l}\text { GCCGTGGTTATCT } \\
\text { CCACGTCCACGGT } \\
\text { GTGTAT }\end{array}$ & -156 & -0.3 & 1.2 & $1 \%$ & 0.1 & 0.5 & $0 \%$ & 0.3 & 0.7 & $3 \%$ & 0.1 & 2.4 & $0 \%$ \\
\hline $\begin{array}{l}\text { MSMEG } \\
-0451\end{array}$ & $\begin{array}{l}\text { oxidoreductase, } \\
\text { FAD-linked }\end{array}$ & $\begin{array}{l}\text { TGACCGGTTTGGT } \\
\text { GAGCGCGTAAAGC } \\
\text { GGTTAT }\end{array}$ & -15 & 0.6 & 1.7 & $1 \%$ & 0.7 & 1.8 & $84 \%$ & 0.6 & 2.2 & $3 \%$ & 0.1 & 3.5 & $0 \%$ \\
\hline $\begin{array}{l}\text { MSMEG } \\
-0670\end{array}$ & $\begin{array}{l}\text { FAD dependent } \\
\text { oxidoreductase }\end{array}$ & $\begin{array}{l}\text { CCTGAGGGTTCGA } \\
\text { CCGGCCGCATTGG } \\
\text { GGGTAT }\end{array}$ & -16 & 0.7 & -0.2 & $21 \%$ & 0.5 & 0.1 & $57 \%$ & 0.3 & 0.3 & $4 \%$ & 0.9 & 2.0 & $27 \%$ \\
\hline
\end{tabular}


Appendix Table 10. Cont.

\begin{tabular}{|c|c|c|c|c|c|c|c|c|c|c|c|c|c|c|c|}
\hline $\begin{array}{l}\text { Primary } \\
\text { Target }\end{array}$ & $\begin{array}{l}\text { Common Name } \\
\text { of Primary } \\
\text { Target }\end{array}$ & Promoter Sequence & $\mathrm{BP}$ & $\mathrm{FC}$ & $\sigma$ & $\mathrm{P}$ & $\mathrm{FC}$ & $\sigma$ & $\mathrm{P}$ & $\mathrm{FC}$ & $\sigma$ & $\mathrm{P}$ & $\mathrm{FC}$ & $\sigma$ & $\mathrm{P}$ \\
\hline $\begin{array}{l}\text { MSMEG } \\
-0671 \\
\end{array}$ & $\begin{array}{l}\text { S-(hydroxymeth } \\
\text { yl)glutathione } \\
\text { dehydrogenase }\end{array}$ & $\begin{array}{l}\text { ACCGGCCGTTTCA } \\
\text { GCGGCTGCGCGTG } \\
\text { GGGTAC }\end{array}$ & -54 & 0.2 & 0.7 & $0 \%$ & 0.7 & 1.0 & $91 \%$ & 1.1 & 1.7 & $27 \%$ & 0.2 & 3.0 & $0 \%$ \\
\hline $\begin{array}{l}\text { MSMEG } \\
\text { _0672 }\end{array}$ & $\begin{array}{l}\text { conserved } \\
\text { hypothetical } \\
\text { protein }\end{array}$ & $\begin{array}{l}\text { CGACCGGGTTTGG } \\
\text { CCGTCCCCACCGC } \\
\text { GGGTAC }\end{array}$ & -57 & 1.1 & 3.5 & $1 \%$ & 1.4 & 3.7 & $68 \%$ & 1.6 & 4.3 & $8 \%$ & 0.3 & 5.5 & $1 \%$ \\
\hline $\begin{array}{l}\text { MSMEG } \\
-0686\end{array}$ & oxidoreductase & $\begin{array}{l}\text { GACCGGCGTTTGG } \\
\text { GCAGTGCCCGCCG } \\
\text { GGGTAC }\end{array}$ & -15 & 0.2 & 2.1 & $0 \%$ & 0.4 & 1.2 & $10 \%$ & 0.3 & 2.3 & $1 \%$ & 0.7 & 2.9 & $26 \%$ \\
\hline $\begin{array}{l}\text { MSMEG } \\
-1076\end{array}$ & $\begin{array}{l}\text { conserved } \\
\text { hypothetical } \\
\text { protein } \\
\end{array}$ & $\begin{array}{l}\text { GCGGAGGTTTCGT } \\
\text { CCGTACCGACGAA } \\
\text { GGGTAT }\end{array}$ & -57 & 0.9 & 2.4 & $1 \%$ & 2.0 & 3.3 & $100 \%$ & 0.7 & 2.4 & $4 \%$ & 0.9 & 4.9 & $9 \%$ \\
\hline $\begin{array}{l}\text { MSMEG } \\
-1605\end{array}$ & $\begin{array}{l}\text { phosphate } \\
\text { transport system } \\
\text { regulatory } \\
\text { protein PhoU }\end{array}$ & $\begin{array}{l}\text { AACCTCGATTGAA } \\
\text { GGGCCCCTCGGAT } \\
\text { GGGTAC }\end{array}$ & -56 & 1.2 & 0.6 & $83 \%$ & 0.6 & 0.1 & $91 \%$ & 0.4 & 0.0 & $4 \%$ & 0.2 & 2.3 & $0 \%$ \\
\hline $\begin{array}{l}\text { MSMEG } \\
-1742\end{array}$ & oxidoreductase & $\begin{array}{l}\text { CCGCGACGTTTCG } \\
\text { GATCGTCGTGTTC } \\
\text { GGGTAC }\end{array}$ & -96 & 1.3 & 2.6 & $34 \%$ & 0.4 & 0.5 & $4 \%$ & 0.2 & 0.7 & $1 \%$ & 0.1 & 5.1 & $0 \%$ \\
\hline $\begin{array}{l}\text { MSMEG } \\
-1758\end{array}$ & $\begin{array}{l}\text { hypothetical } \\
\text { protein }\end{array}$ & $\begin{array}{l}\text { AGCCCGGTTTCAC } \\
\text { CACGGTGTTCGCC } \\
\text { GGGTAG } \\
\end{array}$ & -15 & 0.9 & 1.0 & $85 \%$ & 0.6 & 0.5 & $35 \%$ & 0.5 & 1.6 & $1 \%$ & 1.1 & 2.1 & $66 \%$ \\
\hline $\begin{array}{l}\text { MSMEG } \\
-1770\end{array}$ & $\begin{array}{l}\text { conserved } \\
\text { hypothetical } \\
\text { protein }\end{array}$ & $\begin{array}{l}\text { GATCACGTTTCGG } \\
\text { AACCCGGAATACC } \\
\text { GGGCAT }\end{array}$ & -71 & 2.1 & 1.5 & $97 \%$ & 1.7 & 1.6 & $100 \%$ & 2.1 & 2.7 & $6 \%$ & 0.3 & 5.5 & $1 \%$ \\
\hline
\end{tabular}


Appendix Table 10. Cont.

\begin{tabular}{|c|c|c|c|c|c|c|c|c|c|c|c|c|c|c|c|}
\hline $\begin{array}{l}\text { Primary } \\
\text { Target }\end{array}$ & $\begin{array}{l}\text { Common Name } \\
\text { of Primary } \\
\text { Target }\end{array}$ & Promoter Sequence & BP & $\mathrm{FC}$ & $\sigma$ & $\mathrm{P}$ & $\mathrm{FC}$ & $\sigma$ & $\mathrm{P}$ & $\mathrm{FC}$ & $\sigma$ & $\mathrm{P}$ & $\mathrm{FC}$ & $\sigma$ & $\mathrm{P}$ \\
\hline $\begin{array}{l}\text { MSMEG } \\
-1771\end{array}$ & $\begin{array}{l}\text { methylase, } \\
\text { putative }\end{array}$ & $\begin{array}{l}\text { TCGGAAGGTTTGC } \\
\text { GCGCCCGCGAGAT } \\
\text { GGGTAC }\end{array}$ & -36 & 1.1 & 2.5 & $1 \%$ & 1.3 & 1.8 & $95 \%$ & 1.6 & 2.8 & $11 \%$ & 0.6 & 4.8 & $11 \%$ \\
\hline $\begin{array}{l}\text { MSMEG } \\
-1773\end{array}$ & $\begin{array}{l}\text { conserved } \\
\text { hypothetical } \\
\text { protein }\end{array}$ & $\begin{array}{l}\text { GTTTGAGGTTTAC } \\
\text { CGCAGGCACAAAT } \\
\text { GGGAAT }\end{array}$ & -18 & 0.9 & 1.9 & $0 \%$ & 1.1 & 1.6 & $95 \%$ & 1.1 & 1.7 & $3 \%$ & 0.1 & 4.2 & $0 \%$ \\
\hline $\begin{array}{l}\text { MSMEG } \\
1774\end{array}$ & $\begin{array}{l}\text { conserved } \\
\text { hypothetical } \\
\text { protein }\end{array}$ & $\begin{array}{l}\text { GACGGCGTTTCGC } \\
\text { CGGGAGGCGGCCC } \\
\text { GGGTAG }\end{array}$ & -71 & 0.3 & 2.3 & $0 \%$ & 1.2 & 2.4 & $76 \%$ & 1.3 & 2.3 & $5 \%$ & 0.0 & 4.9 & $0 \%$ \\
\hline $\begin{array}{l}\text { MSMEG } \\
-1777\end{array}$ & UsfY protein & $\begin{array}{l}\text { GCCCGGGTTTCAC } \\
\text { ACCGACCGTCCCC } \\
\text { GGGTAG }\end{array}$ & -76 & 0.9 & 2.7 & $0 \%$ & 1.3 & 2.5 & $97 \%$ & 1.2 & 3.4 & $10 \%$ & 0.4 & 5.7 & $1 \%$ \\
\hline $\begin{array}{l}\text { MSMEG } \\
-1794 \\
\end{array}$ & dehydrogenase & $\begin{array}{l}\text { TGCTCGTGTTCGG } \\
\text { GGTCATATCTGGC } \\
\text { GGGTAC }\end{array}$ & -22 & 1.1 & 0.3 & $47 \%$ & 0.6 & 0.1 & $81 \%$ & 0.4 & 0.4 & $1 \%$ & 0.0 & 2.4 & $0 \%$ \\
\hline $\begin{array}{l}\text { MSMEG } \\
-1802 \\
\end{array}$ & ChaB protein & $\begin{array}{l}\text { TCGAGGGTTTCCC } \\
\text { GAATGCCGACCTT } \\
\text { GGGCAT }\end{array}$ & -70 & 1.1 & 1.4 & $7 \%$ & 0.8 & 0.0 & $89 \%$ & 0.4 & 0.8 & $2 \%$ & -0.3 & 1.8 & $0 \%$ \\
\hline $\begin{array}{l}\text { MSMEG } \\
2112\end{array}$ & secreted protein & $\begin{array}{l}\text { AATTGACGTTTCT } \\
\text { GTAGGACGCCAGC } \\
\text { GGGTAT }\end{array}$ & -31 & 1.2 & 1.6 & $18 \%$ & 1.0 & 0.9 & $96 \%$ & 1.7 & 3.2 & $15 \%$ & 0.3 & 4.6 & $1 \%$ \\
\hline $\begin{array}{l}\text { MSMEG } \\
2347\end{array}$ & $\begin{array}{l}\text { phytoene } \\
\text { dehydrogenase }\end{array}$ & $\begin{array}{l}\text { CCGGACGTTTGTA } \\
\text { GCCCGCCGCCTGC } \\
\text { GGGTAT }\end{array}$ & -104 & 0.2 & 1.7 & $0 \%$ & 0.6 & 0.9 & $55 \%$ & 0.8 & 1.8 & $21 \%$ & 0.4 & 1.9 & $1 \%$ \\
\hline
\end{tabular}


Appendix Table 10. Cont.

\begin{tabular}{|c|c|c|c|c|c|c|c|c|c|c|c|c|c|c|c|}
\hline $\begin{array}{l}\text { Primary } \\
\text { Target }\end{array}$ & $\begin{array}{l}\text { Common Name } \\
\text { of Primary } \\
\text { Target }\end{array}$ & Promoter Sequence & BP & $\mathrm{FC}$ & $\sigma$ & $\mathrm{P}$ & $\mathrm{FC}$ & $\sigma$ & $\mathrm{P}$ & $\mathrm{FC}$ & $\sigma$ & $\mathrm{P}$ & $\mathrm{FC}$ & $\sigma$ & $\mathrm{P}$ \\
\hline $\begin{array}{l}\text { MSMEG } \\
-2415\end{array}$ & $\begin{array}{l}\text { hemerythrin } \\
\text { HHE cation } \\
\text { binding region }\end{array}$ & $\begin{array}{l}\text { CTCAACGGTTGAA } \\
\text { CCCGGCCGGTAGG } \\
\text { GGGTAG }\end{array}$ & -68 & 1.6 & 1.5 & $17 \%$ & 1.1 & 1.1 & $99 \%$ & 1.1 & 1.2 & $10 \%$ & 0.6 & 4.5 & $10 \%$ \\
\hline $\begin{array}{l}\text { MSMEG } \\
\_2958\end{array}$ & $\begin{array}{l}\text { conserved } \\
\text { hypothetical } \\
\text { protein }\end{array}$ & $\begin{array}{l}\text { CACGACGGTTCGC } \\
\text { CAGGTCGCCGCGC } \\
\text { GGGTAT }\end{array}$ & -31 & 1.4 & 1.3 & $96 \%$ & 1.0 & 1.1 & $98 \%$ & 1.2 & 3.1 & $28 \%$ & 0.1 & 5.1 & $0 \%$ \\
\hline $\begin{array}{l}\text { MSMEG } \\
-3022\end{array}$ & $\begin{array}{l}\text { transglycosylase } \\
\text { associated } \\
\text { protein }\end{array}$ & $\begin{array}{l}\text { GCCGCCGTTTACG } \\
\text { CCGCCGACAGCCG } \\
\text { GGGTAT }\end{array}$ & -37 & 1.7 & 2.8 & $34 \%$ & 1.6 & 1.4 & $94 \%$ & 2.4 & 3.3 & $7 \%$ & -0.4 & 4.5 & $2 \%$ \\
\hline $\begin{array}{l}\text { MSMEG } \\
-3289\end{array}$ & gp61 protein & $\begin{array}{l}\text { CCTTGACGTTTGA } \\
\text { ACGTGCAGCGGGA } \\
\text { GGGTAC }\end{array}$ & -36 & 1.1 & 1.7 & $96 \%$ & 0.5 & 0.7 & $8 \%$ & 0.4 & 1.1 & $4 \%$ & 1.2 & 3.3 & $36 \%$ \\
\hline $\begin{array}{l}\text { MSMEG } \\
-3443\end{array}$ & $\begin{array}{l}\text { hypothetical } \\
\text { protein }\end{array}$ & $\begin{array}{l}\text { GAACGCGTTTGTC } \\
\text { CGAGCGTCGCTGG } \\
\text { GGATAT }\end{array}$ & -50 & 1.6 & 0.9 & $100 \%$ & 0.5 & -0.6 & $34 \%$ & 0.6 & 0.4 & $2 \%$ & -0.1 & 2.4 & $0 \%$ \\
\hline $\begin{array}{l}\text { MSMEG } \\
-3543\end{array}$ & $\begin{array}{l}\text { soluble secreted } \\
\text { antigen MPT53 }\end{array}$ & $\begin{array}{l}\text { CGCACGGTTCCTA } \\
\text { CCGTCGTGCCACA } \\
\text { GGGTGT }\end{array}$ & -52 & 1.2 & 0.8 & $97 \%$ & 0.8 & 0.2 & $94 \%$ & 0.4 & 0.9 & $5 \%$ & 0.0 & 2.8 & $0 \%$ \\
\hline $\begin{array}{l}\text { MSMEG } \\
-4072\end{array}$ & $\begin{array}{l}\text { ISMsm5, } \\
\text { transposase }\end{array}$ & $\begin{array}{l}\text { TAATTAGTTTACA } \\
\text { GTGTGGGATGATG } \\
\text { GTGTAT }\end{array}$ & -19 & -0.8 & 2.0 & $45 \%$ & -0.1 & 2.8 & $0 \%$ & 0.4 & 4.2 & $1 \%$ & 1.4 & 1.4 & $84 \%$ \\
\hline $\begin{array}{l}\text { MSMEG } \\
-4791\end{array}$ & $\begin{array}{l}\text { IS1096, tnpR } \\
\text { protein }\end{array}$ & $\begin{array}{l}\text { TCAGCTGCTTTCG } \\
\text { CGCTGTGATCGAG } \\
\text { GGGTCT }\end{array}$ & -59 & -0.4 & 4.7 & $2 \%$ & -0.2 & 0.8 & $0 \%$ & 0.4 & 5.2 & $1 \%$ & 1.6 & 2.3 & $95 \%$ \\
\hline
\end{tabular}


Appendix Table 10. Cont.

\begin{tabular}{|c|c|c|c|c|c|c|c|c|c|c|c|c|c|c|c|}
\hline $\begin{array}{l}\text { Primary } \\
\text { Target }\end{array}$ & $\begin{array}{l}\text { Common Name } \\
\text { of Primary } \\
\text { Target }\end{array}$ & Promoter Sequence & $\mathrm{BP}$ & $\mathrm{FC}$ & $\sigma$ & $\mathrm{P}$ & $\mathrm{FC}$ & $\sigma$ & $\mathrm{P}$ & $\mathrm{FC}$ & $\sigma$ & $\mathrm{P}$ & $\mathrm{FC}$ & $\sigma$ & $\mathrm{P}$ \\
\hline $\begin{array}{l}\text { MSMEG } \\
-4918\end{array}$ & $\begin{array}{l}\text { 1,4-alpha-gluca } \\
\text { n branching } \\
\text { enzyme }\end{array}$ & $\begin{array}{l}\text { ACTTTGTGGTTGG } \\
\text { ACATGGAGGCACT } \\
\text { GGGTAT }\end{array}$ & -179 & 0.0 & 1.1 & $0 \%$ & 0.7 & 1.2 & $75 \%$ & 0.4 & 1.1 & $1 \%$ & -0.8 & 2.9 & $32 \%$ \\
\hline $\begin{array}{l}\text { MSMEG } \\
-5189\end{array}$ & oxidoreductase & $\begin{array}{l}\text { GGCGGCGGTTGCC } \\
\text { GCGATCGATGCGG } \\
\text { GGGTAT }\end{array}$ & -32 & 0.6 & 1.0 & $19 \%$ & 0.5 & 0.5 & $48 \%$ & 0.5 & 0.6 & $10 \%$ & 1.1 & 3.0 & $69 \%$ \\
\hline $\begin{array}{l}\text { MSMEG } \\
-5343\end{array}$ & $\begin{array}{l}\text { conserved } \\
\text { hypothetical } \\
\text { protein }\end{array}$ & $\begin{array}{l}\text { CCTGAGGTTTCAC } \\
\text { GCGTTCGCCGGAT } \\
\text { GGCTAT }\end{array}$ & -41 & 1.3 & 0.6 & $89 \%$ & 1.1 & -0.1 & $98 \%$ & 0.4 & 0.1 & $1 \%$ & -0.6 & 3.2 & $9 \%$ \\
\hline $\begin{array}{l}\text { MSMEG } \\
5543 \\
\end{array}$ & $\begin{array}{l}\text { hypothetical } \\
\text { protein }\end{array}$ & $\begin{array}{l}\text { TGTGCGTTTCGAC } \\
\text { ATGCGTGAAGGCT } \\
\text { GGGTAG }\end{array}$ & -84 & 0.5 & 2.2 & $0 \%$ & 1.8 & 1.3 & $99 \%$ & 2.4 & 3.0 & $11 \%$ & -0.5 & 4.0 & $3 \%$ \\
\hline $\begin{array}{l}\text { MSMEG } \\
5617\end{array}$ & $\begin{array}{l}\text { immunogenic } \\
\text { protein MPT63 }\end{array}$ & $\begin{array}{l}\text { TACCGATGTTTTC } \\
\text { CTCCTGACGAGGC } \\
\text { GGGTAT }\end{array}$ & -77 & -0.2 & 0.2 & $0 \%$ & 1.6 & 1.5 & $99 \%$ & 0.5 & -0.1 & $3 \%$ & 0.5 & 1.8 & $3 \%$ \\
\hline $\begin{array}{l}\text { MSMEG } \\
-5872 \\
\end{array}$ & $\begin{array}{l}\text { DNA-binding } \\
\text { response } \\
\text { regulator PhoP }\end{array}$ & $\begin{array}{l}\text { CGTGGGTTTCGGG } \\
\text { CGGCTTCCTGCCG } \\
\text { GGGTAT }\end{array}$ & -78 & 1.1 & 2.0 & $24 \%$ & 0.1 & 1.7 & $0 \%$ & -0.2 & 1.9 & $0 \%$ & -0.4 & 5.3 & $1 \%$ \\
\hline $\begin{array}{l}\text { MSMEG } \\
-6212\end{array}$ & $\begin{array}{l}\text { hemerythrin } \\
\text { HHE cation } \\
\text { binding domain } \\
\text { subfamily } \\
\text { protein, putative }\end{array}$ & $\begin{array}{l}\text { ACGCGCTGTTTGG } \\
\text { CAACGGGTCTGAC } \\
\text { GGGTAT }\end{array}$ & -58 & 1.6 & 1.7 & $70 \%$ & 1.0 & 1.8 & $98 \%$ & 1.7 & 3.6 & $13 \%$ & 0.2 & 5.2 & $0 \%$ \\
\hline $\begin{array}{l}\text { MSMEG } \\
-6213 \\
\end{array}$ & $\begin{array}{l}\text { Manganese } \\
\text { containing } \\
\text { catalase }\end{array}$ & $\begin{array}{l}\text { GACCGCTGTTTGG } \\
\text { GGTTCTCGGCGCT } \\
\text { GGGTAT }\end{array}$ & -47 & 2.0 & 0.7 & $99 \%$ & 1.0 & -0.1 & $94 \%$ & 1.0 & 0.9 & $55 \%$ & -0.1 & 4.5 & $0 \%$ \\
\hline
\end{tabular}


Appendix Table 10. Cont.

\begin{tabular}{|c|c|c|c|c|c|c|c|c|c|c|c|c|c|c|c|}
\hline $\begin{array}{l}\text { Primary } \\
\text { Target }\end{array}$ & $\begin{array}{l}\text { Common Name } \\
\text { of Primary } \\
\text { Target }\end{array}$ & Promoter Sequence & $\mathrm{BP}$ & $\mathrm{FC}$ & $\sigma$ & $\mathrm{P}$ & $\mathrm{FC}$ & $\sigma$ & $\mathrm{P}$ & $\mathrm{FC}$ & $\sigma$ & $\mathrm{P}$ & $\mathrm{FC}$ & $\sigma$ & $\mathrm{P}$ \\
\hline $\begin{array}{l}\text { MSMEG } \\
-6467\end{array}$ & $\begin{array}{l}\text { starvation-induc } \\
\text { ed DNA } \\
\text { protecting } \\
\text { protein }\end{array}$ & $\begin{array}{l}\text { CGCTGTGATTAGT } \\
\text { GCCCGGCACTGCC } \\
\text { GGGTAC }\end{array}$ & -43 & 1.5 & 2.7 & $2 \%$ & 1.6 & 1.3 & $99 \%$ & 1.7 & 2.4 & $11 \%$ & 0.3 & 4.7 & $1 \%$ \\
\hline $\begin{array}{l}\text { MSMEG } \\
-6616\end{array}$ & $\begin{array}{l}\text { S- } \\
\text { (hydroxymethyl) } \\
\text { glutathione } \\
\text { dehydrogenase }\end{array}$ & $\begin{array}{l}\text { GGCCAAGGTTTGG } \\
\text { GCCAGCTCCGGTG } \\
\text { GGGTAG }\end{array}$ & -37 & 1.2 & 0.9 & $4 \%$ & 0.7 & 0.7 & $87 \%$ & 1.1 & 2.0 & $6 \%$ & 1.0 & 2.8 & $56 \%$ \\
\hline
\end{tabular}

(C) 2010 by the authors; licensee Molecular Diversity Preservation International, Basel, Switzerland. This article is an open-access article distributed under the terms and conditions of the Creative Commons Attribution license (http://creativecommons.org/licenses/by/3.0/). 